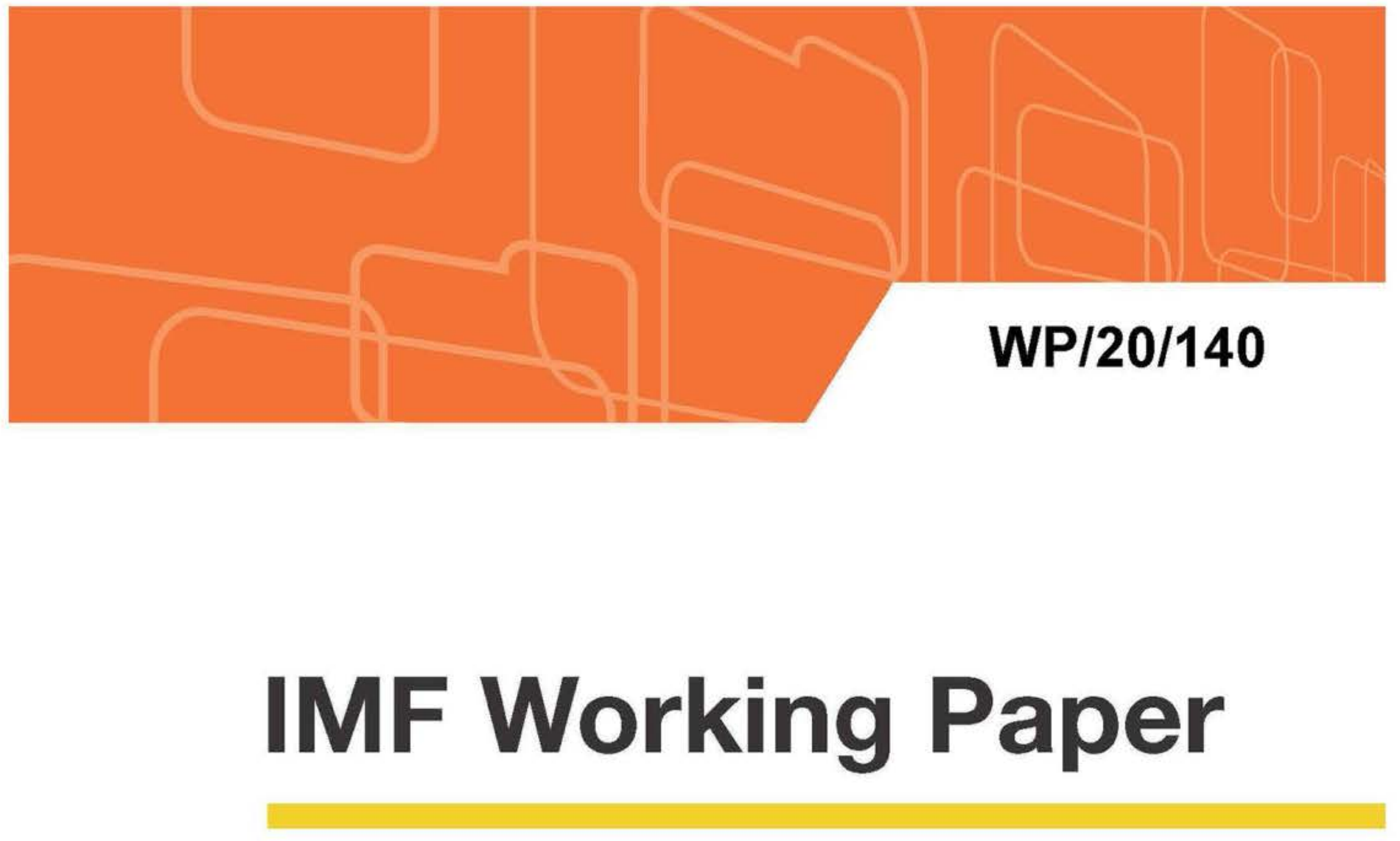

\title{
Forbearance Patterns in the Post-Crisis Period
}

by Katharina Bergant and Thore Kockerols

IMF Working Papers describe research in progress by the author(s) and are published to elicit comments and to encourage debate. The views expressed in IMF Working Papers are those of the author(s) and do not necessarily represent the views of the IMF, its Executive Board, or IMF management. 


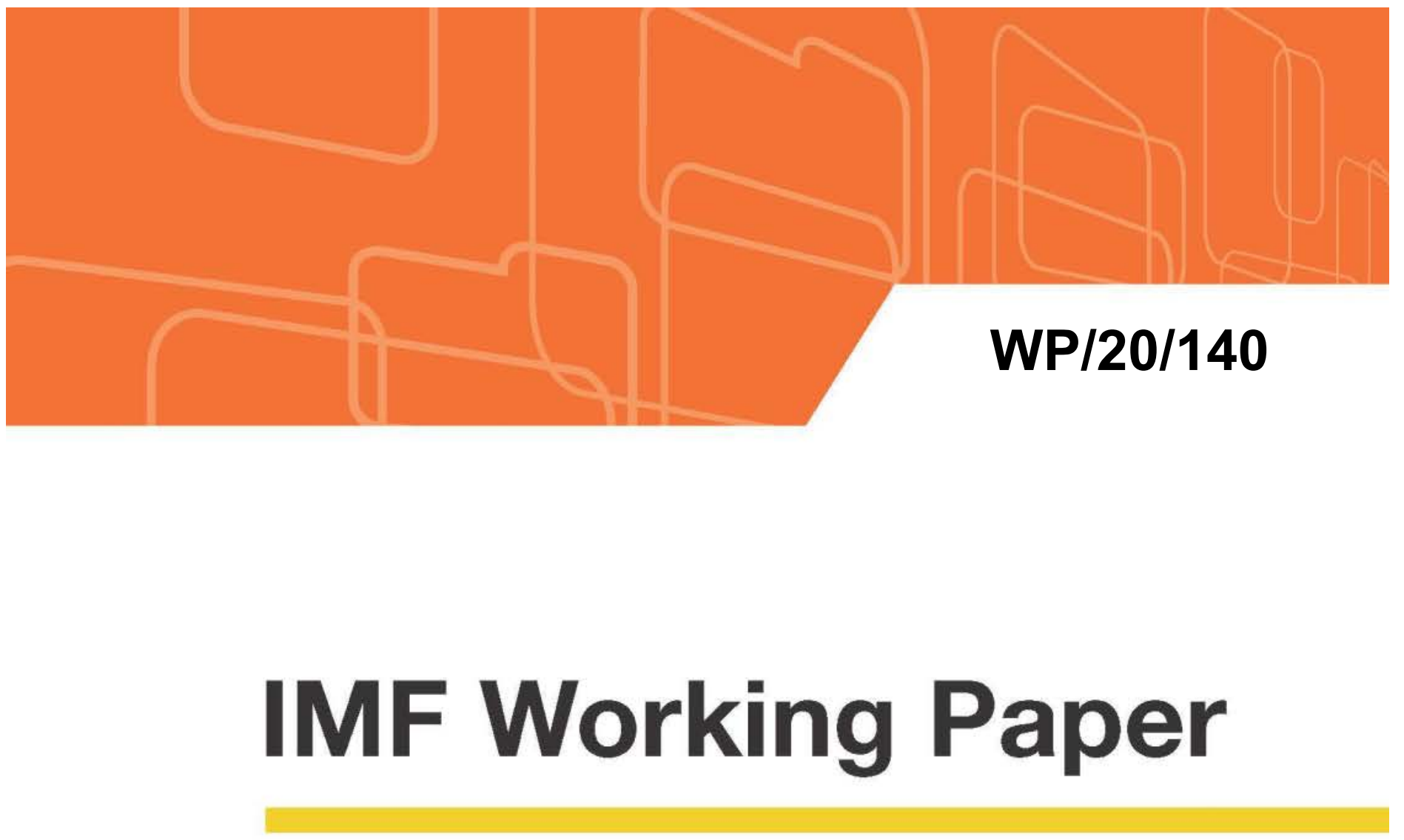

\section{Forbearance Patterns in the Post-Crisis Period}

by Katharina Bergant and Thore Kockerols

IMF Working Papers describe research in progress by the author(s) and are published to elicit comments and to encourage debate. The views expressed in IMF Working Papers are those of the author(s) and do not necessarily represent the views of the IMF, its Executive Board, or IMF management. 
IMF Working Paper

Research Department

Forbearance Patterns in the Post-Crisis Period*

Prepared by Katharina Bergant and Thore Kockerols

Authorized for distribution by Maria Soledad Martinez Peria

July 2020

IMF Working Papers describe research in progress by the author(s) and are published to elicit comments and to encourage debate. The views expressed in IMF Working Papers are those of the author(s) and do not necessarily represent the views of the IMF, its Executive Board, or IMF management.

\begin{abstract}
Using supervisory loan-level data on corporate loans, we show that banks facing high levels of nonperforming loans relative to their capital and provisions were more likely to grant forbearance measures to the riskiest group of borrowers. More specifically, we find that risky borrowers are more likely to get an increase in the overall limit or the maturity of a loan product from a distressed lender. As a second step, we analyse the effectiveness of this practice in reducing the probability of default. We show that the most common measure of forbearance is effective in the short run but no forbearance measure significantly reduces the probability of default in the long run. Our evidence also suggests that forbearance and new lending are substitutes for banks, as high shares of forbearance are negatively correlated with new lending to the same group of borrowers. Taken together, these findings can help policy makers shape surveillance and regulation in a future recovery from the Covid-19 pandemic.
\end{abstract}

JEL Classification Numbers: G21, G28, G33

Keywords: Non-Performing Loans, Zombie Lending, Banking Regulation

Author's E-Mail Addresses: KBergant@,imf.org; Thore.Kockerols@,Norges-Bank.no

\footnotetext{
* The views expressed in this paper are those of the authors and do not necessarily represent the views of the International Monetary Fund or the Norges Bank. We thank Philip Lane, Fergal McCann, Bill Mendenhall, Steven Ongena, Jonathan Rice, Jochen Güntner, Yannick Timmer, as well as participants of the 2018 ASSA Meeting, 42nd Symposium of the Spanish Economic Association, the seminar series at the ECB, the IMF, as well as the Central Bank of Ireland, the Irish Economic Association Conference 2017, and the RCEA Macro-MoneyFinance Workshop for valuable discussions and comments. Katharina Bergant is grateful for financial support from the Grattan Foundation. Thore Kockerols gratefully acknowledges the support of the Laboratory of Excellence on Financial Regulation (Labex ReFi), and PRES heSam under the reference ANR-10-LABX-0095. All errors are our own.
} 


\section{Introduction}

In the recent financial crisis, the banking sector was simultaneously both the trigger as well as one of the most affected sectors in many countries. Corporate defaults, a crash in house prices, and high unemployment threatened the health of banks' balance sheets. Under these circumstances, lenders and borrowers found it in their interest to keep otherwise non-performing loans alive by preventing a risky borrower's default. Terms such as "evergreening", "zombie lending", or banks "gambling for resurrection" emerged in the economic literature to describe the practice of granting concessions to troubled borrowers. Whilst this can be economically useful under some circumstances, it can be used by banks to conceal potential losses. This can cause systemic risk, increase uncertainty about the quality of banks' assets, and undermine trust in the banking sector's solvency, which calls for regulators to monitor and prevent the establishment of this practice.

Using loan-level data on the commercial loans of all Irish banks, we study the patterns and the effectiveness of forbearance after the recent Global Financial Crisis and provide evidence for several correlations observed in banks under stress. In our empirical setting, we distinguish between extensions in the overall credit limit or the maturity of the loan, a stop in amortisation, a relative decrease in the interest rate, and a rollover of the exposure. Using a standard logit model saturated with various fixed effects, we find that the riskiest borrowers are more likely to be granted a forbearance measure if the lender is facing high levels of non-performing loans (NPLs) relative to its capital and provisions. For the positive relationship between banks' stress levels - measured by the Texas Ratio - and a higher probability of granting forbearance, we offer an explanation through the current regulatory framework. When the reporting of default is seen as a conscious decision of the bank and the firm, banks face an incentive not to flag loans as non-performing but to grant forbearance because of the impact on their profitability and ultimately their capital ratios (Eisfeldt and Rampini, 2008). Furthermore, since banks do not know the persistence of the shock hitting firms it is rational to practice forbearance under the assumption that it might help the firm survive. Besides the incentives, forbearance can be one way of releasing stress on borrowers and banks if it is effective in bringing down the probability of default and thereby helping the overall economy. 
As a second step, we look at the effectiveness of forbearance as a mean of preventing default. We show that the most frequent measure - a limit extension - is effective in reducing the probability of default up to one year ahead. For a longer time horizon and other forbearance measures, we find that treated borrowers are in fact more likely to default compared to their peers within the same risk category. While this can be due to several mechanisms (e.g. selection bias within a risk category), we can show that forbearance did not prevent default in the long run after the Global Financial Crisis. This finding should make policy makers aware of potential risks of forbearance in a future recovery from the Covid-19 crisis. As disentangling illiquidity from insolvency becomes easier in later phases of the crisis, our findings may help policy makers to shape a targeted approach regarding the surveillance of the banking sector.

Finally, the question arises over whether or not new lending is subdued because capital and other resources within the bank are allocated to forborne loans. We present evidence that lending and forbearance might be treated as substitutes by banks. Within buckets of similar loans, we find that the share of forbearance is negatively related with the issuance of new credit.

A significant caveat of our administrative data is that we do not observe the borrowers identity across banks ${ }^{1}$. This brings identification challenges when trying to single out supply factors and to properly account for substitution of credit from one bank to another bank.

We contribute to a strand of literature focused on forbearance techniques of banks which has emerged in the last two decades. For Japan, empirical evidence shows that troubled banks allocated credit to severely impaired borrowers to avoid the realisation of losses on their own balance sheets (e.g. Peek and Rosengren (2005), Sekine et al. (2003), and Watanabe (2010)). Analysing the driving mechanism of forbearance during the country's "lost decade", Caballero et al. (2008) use the term "zombie lending" for credit to unprofitable firms at interest rates below market values. Besides the hazard for banks themselves, the authors show that this misallocation of credit towards otherwise insolvent borrowers had significant negative effects on the real economy. The presence of zombie firms was found to depress job creation, deter the entry of healthy firms, and to decrease employment and investment of healthy firms. Using the effects following capital injections for Japanese financial institutions, Giannetti and Simonov (2013) show that troubled banks that remained under-capitalized were more likely to engage in

\footnotetext{
${ }^{1}$ We do observe borrower IDs within a bank so we can link one borrower with several loan products.
} 
"evergreening" by maintaining relationships with weak borrowers.

More recently, it became clearer that Japan was not an exception (Acharya et al., 2018). Homar et al. (2015) look at European banks and find that weak banks are more likely to grant concessions to weak borrowers. The authors call for more empirical work regarding patterns of forbearance as an important factor in the slow recovery after the Global Financial Crisis. Using the Italian credit registry, Schivardi et al. (2017) show that Italian banks with relatively low capital levels were less likely to cut credit to non-viable firms after the Global Financial Crisis. While they show that measures of real effects, such as TFP growth, were not significantly affected by the misallocation, it did lead to an increase in the failure rate of healthy firms while it reduced the failure rate of non viable firms. Using the same data, Accornero et al. (2017) confirm the negative correlation between NPL ratios and credit growth but show that for the Italian case, this was caused by constrained demand. Acharya et al. (2019) use the announcement of the Outright Monetary Transactions (OMT) as an event on which to identify "zombie lending" patterns for European banks. Institutions which were not sufficiently recapitalised in the wake of the OMT announcement were more likely to extend loans to weak firms instead of their more creditworthy peers who would have been able to invest credit more profitably. This resulted in significant real effects, most notably a slow down of the economic recovery in the post-crisis period.

Our analysis is also motivated by existing work focused on the incentives for banks to engage in forbearance and therefore relatively risky lending. Aiyar et al. (2015) and Kang and Jassaud (2015) illustrate how the reclassification of outstanding to non-performing loans lower the banks' net operating income, require them to raise provisioning levels, and tie up more equity capital due to higher risk weights on impaired assets. Keuschnigg and Kogler (2017) present a theoretical model showing that weak banks try to avoid writing off non-performing loans in order to prevent a violation of regulatory requirements or even insolvency. This literature also emphasizes possible negative consequences of these patterns for the financial stability when banks do not "clean up their balance sheets" (Diamond and Rajan, 2011). Analysing the case of China, Zhang et al. (2016) show that high NPL ratios are associated with riskier lending, potentially increasing individual institutions credit risk and threatening financial stability. Huizinga and Laeven (2012) show that distressed banks in the US used discretion in accounting during the Global Financial Crisis in order to inflate the book value of their assets which results in a distorted view of the 
financial health of these institutions. In addition, Bonaccorsi di Patti and Kashyap (2017) show that banks are able to recover significantly faster from large adverse shocks if they manage risky clients more aggressively and thereby reduce credit risk.

With our analysis we reach some novel results. First, we argue that capitalisation is not the only determinant factor of forbearance for banks. As can be seen in recent stress tests (EBA, 2016b), some of the banks in our sample have been sufficiently re-capitalised since the crisis through a public bailout, so that they now comfortably exceed regulatory requirements. However, NPLs are at very high levels by any standards, which can pose a threat to capitalisation levels under even moderate economic stress (IMF, 2016). Therefore, we argue that the quality of a lender's loan book must be considered when analysing the determinants of "zombie lending". Secondly, we exploit the quality of the loan level data to measure forbearance techniques using more definitions than are common in the literature. We suggest that financial pressure in times of crises creates incentives for different types of forbearance other than subsidised lending through a lower interest rate. More specifically, we analyse whether banks extend credit limits or maturities, or opt to grant other measures such as a stop in amortisation or a rollover of a loan product. Furthermore, the granular loan-level data allow us to suggest that a limit extension has been effective in bringing down the probability of default up to one year but no forbearance measure has been effective in the long run for the banking system. Using a standard logit-hazard model, we show the relationship between the different forbearance measures and the probability of default across various time horizons. Finally, the evidence suggests that forbearance ties up banks' resources that might have been used for new lending. We conclude our empirical analysis with a correlation analysis that reveals the negative relationship between forbearance and new lending.

In Section 2, we explain the conceptual framework, the different forbearance measures and offer an explanation as to why banks face an incentive to engage in forbearance within the current regulatory framework. Section 3 introduces the data and lays out our analysis of the forbearance patterns. Section 4 elaborates on the effectiveness of the different forbearance measures in avoiding default, and Section 5 looks at possible correlations between forbearance and new lending. Finally, Section 6 concludes. 


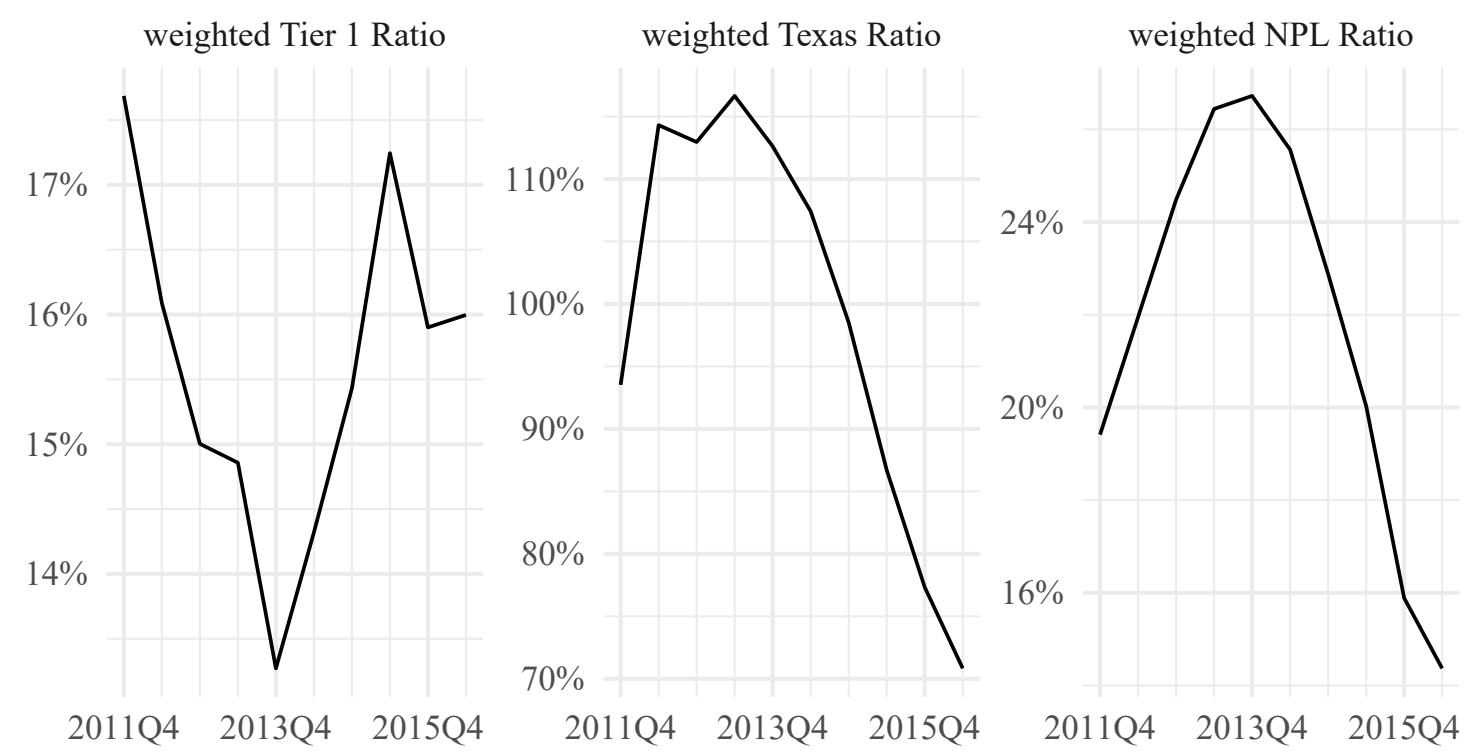

Figure 1: Weighted Tier 1 Capital Ratio and Texas Ratio of Irish banks. Weighted by Total Assets of respective bank.

Source: Author's calculations; Data: SnL

\section{Conceptual Framework}

\subsection{The Crisis and the Irish Case}

Ireland experienced one of the worst banking crises in the aftermath of the recent Global Financial Crisis. It originated from a devastating boom-bust cycle in the domestic property market which was financed by bank loans. While the economic growth in the years leading up to 2000 can be interpreted as a healthy convergence of the "Celtic Tiger" with the rest of the European Union, the surge in output in 2003-2007 turned out to be of a different kind: a construction boom (Honohan, 2010). Banks became highly exposed to the housing market through the extremely rapid credit expansion to home owners and property developers. As a consequence of the shift in international financial markets in $2007 / 2008$, Irish banks faced difficulties to maintain funding while domestic investors pulled back from the property market. After prices declined sharply and construction activities collapsed, banks faced an unprecedented increase in NPLs. Finally, public funds had to be used in order to recapitalise the most significant credit institutions in Ireland (Lane, 2011).

The banks' recovery was then shaped by two stylised facts: (i) a fast recapitalisation of banks 
due to the public bail-out but (ii) threatening levels of NPLs on their balance sheets. We show these two developments for Irish banks in Figure 1. On the left side, we look at Tier 1 capital as an indicator of the health of an institution's balance sheet. ${ }^{2}$ We can see that after the public bailouts of banks in response to the crisis, the ratio of Tier 1 capital to risk weighted assets (Tier 1 Capital Ratio) has levelled off well above the regulatory requirement of $8 \%$ and the European average of $14.1 \%{ }^{3}$ On the right side, we analyse the NPL ratio which is at very high levels throughout and peaks only in 2013 and descends thereafter. In the middle panel of Figure 1, we analyse the Texas Ratio, which indicates how close the bank is to the regulatory constraints due to credit risk. ${ }^{4}$ The measure is defined as:

$$
\text { Texas Ratio }=\frac{\text { Impaired Loans }+ \text { Loans } 90 \text { days past due but not impaired }}{\text { Tangible Equity }+ \text { Loan Loss Provisions }} .
$$

Intuitively, a value above $100 \%$ is widely considered to be critical and we can see that the Irish banking sector only recovered to below this threshold in 2014. It is clear from Figure 1 that the development of the Texas Ratio is driven by the NPL ratio. Evidently, Ireland continues to suffer from high levels of impaired loans as a legacy from the Global Financial Crisis. Besides the decline in house prices and resulting wealth effects, unemployment and contractionary fiscal policy have made it impossible for some borrowers to pay back their loans. Hence, NPL ratios have risen to approximately four times the European average, driving the Texas Ratio to critical levels throughout our period of observation.

The high levels of the Texas Ratio suggest a threatening sensitivity to credit risk, which has been confirmed by recent stress tests, such as the latest Financial Sector Assessment Program of the International Monetary Fund and European Banking Authority's stress tests (EBA (2016a); IMF (2016)). In Figure 2, we use data from EBA (2016a) to illustrate this risk: although Irish banks seem well capitalised in normal economic conditions, the stress test points out that regulatory requirements may not be reached under the adverse scenario. In addition, compared to other Euro Area countries, the difference of Tier 1 capital levels between the baseline and adverse scenario turns out to be the largest for Ireland.

\footnotetext{
${ }^{2}$ Tier 1 capital is composed of Common Equity Tier 1 and Additional Tier 1 capital, which is available to the institution for unrestricted and immediate use to cover risks or losses as soon as these occur.

${ }^{3}$ Through the public bank bailouts, $99.9 \%$ of Allied Irish Banks and $15 \%$ of Bank of Ireland became state-owned.

${ }^{4}$ Developed by Gerard Cassidy and others at RBC Capital Markets, the Texas Ratio got its name from its use to analyse weak banks in Texas during the 1980s.
} 


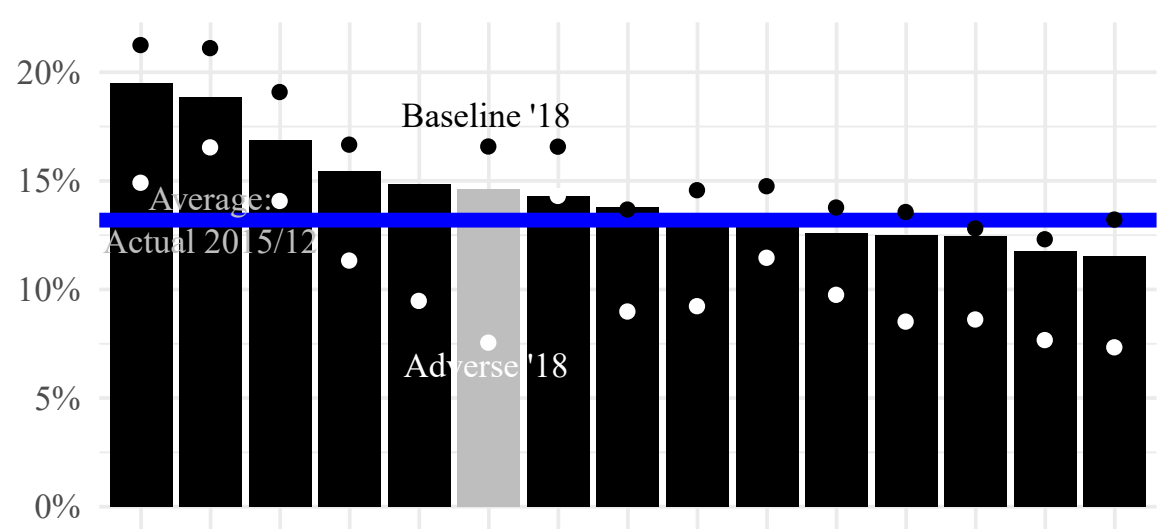

FI SE DK BE DE IE NO NL HU PL FR GB ES IT AT

Figure 2: The y-axis measures the Tier 1 Ratios for banks residing in the respective countries under different scenarios. The black (white) dot represents the Tier 1 Ratio under the baseline (adverse) scenario in 2018. The blue line shows the European average.

Source: Author's calculations; Data: EBA (2016a)

A breakdown of the drivers behind this large gap, shown in Figure 3, reveals that credit risk is the main contributor and accounts for a 6 percentage point difference in the Tier 1 capital ratio between the two scenarios. ${ }^{5}$

\subsubsection{Data}

We use the commercial loan level data from the Central Bank of Ireland provided by Irish banks in biannual frequency from 2011 Q4 up to 2016 Q2. This covers all loans to large corporates, small and medium enterprises (SMEs), and Micro SMEs including loan-specific as well as borrowerspecific characteristics. Therefore, while most of the previous literature considered only listed firms, we are able to analyse lending to any type of firm that borrows from Irish Banks in Ireland. The loan-specific characteristics contain information on product type, maturity, interest rate, the repayment schedule, whether the loan is securitised, and a mapped rating of the risk of the loan. The latter come from the banks' internal Probability-of-Default (PD) models but are homogenized by the Central Bank of Ireland by ensuring that the rating classes correspond to similar probabilities of default. The borrower-specific characteristics include information about the firm's sector and segment.

\footnotetext{
${ }^{5}$ In comparison, Italy is less affected by credit risk and is projected to have higher profits under the adverse scenario.
} 


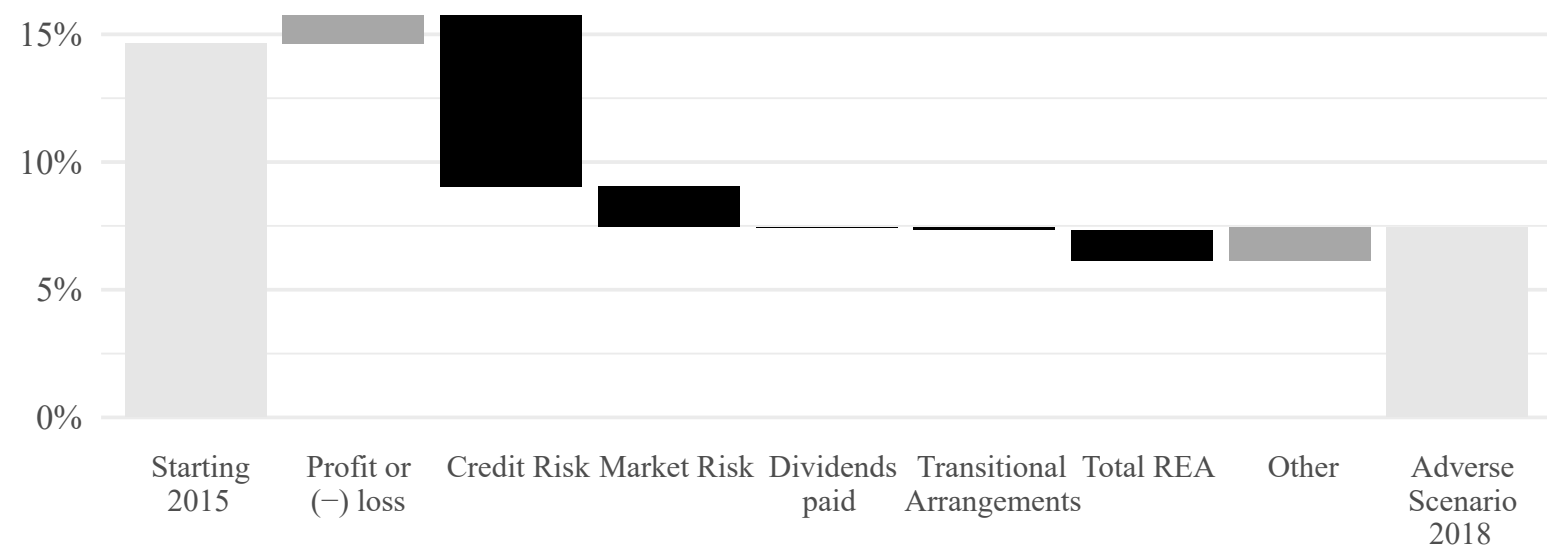

Figure 3: Drivers of changes in the Tier 1 capital ratio from Actual 12/2015 to Adverse 12/2018. Credit Risk refers to: Impairment or (-) reversal of impairment on financial assets. Profit or (-) loss refers to: profit or (-) loss before tax from continuing operations before credit risk and market risk losses.

Source: Author's calculations; Data: EBA (2016a)

We have 1,686,325 observations (loan $\times$ time) and 244,908 borrowers in our sample. Once a loan defaults, the borrower and all of the related loans are no longer included in the sample. The data covers the 26 Irish counties, 8 sectors, 3 segments (Corporate, SME and micro SME), and 4 product types (leasing/hire purchase, overdraft, term loan and other).

A caveat of this confidential data is that we do not obtain the firms' names. This has two consequences: first, we cannot enrich the data with balance sheet information in order to control for firm characteristics. Secondly, we cannot identify the same firm across banks. While the data allow us to identify a borrower having several loan products within a bank, we cannot control for the fact that the firm might have a relationship to another bank. However, Albertazzi and Marchetti (2010) use the Italian credit registry to show that the ability of borrowers to compensate through substitution across banks appears to have been limited after Lehman's collapse.

\subsection{Forbearance}

\subsubsection{Types of Forbearance}

In this section, we define and explain the different forbearance measures that we construct from our data. We exploit the quality and granularity of the Irish commercial loan level data to 
measure forbearance techniques along several definitions. The first definition of forbearance we consider is when banks (temporarily) suspend instalments and allow borrowers to only make interest payments. This measure, referred to as an "amortisation stop", ensures that the outstanding amount on the loan remains constant until further agreement or maturity. This is straight-forward to detect since banks report any changes in the amortisation status of each loan. ${ }^{6}$ Furthermore, a bank can grant two types of loan extensions. First, loans can be extended by increasing the total limit that can be drawn down by the borrower. This measure is especially common for overdrafts. In the framework of forbearance, the idea is that a borrower needs more credit, e.g. to cover current expenses or even to fulfil payments that are outstanding on another existing loan product. We define this measure as a positive change in the total limit that can be drawn by a borrower. Second, the loan's maturity can be extended by pushing back the due date of the loan. Non-amortising loans therefore become due at a later date. For loans with constant repayments, this can result in smaller instalments and therefore a lighter financial burden for the company over time. In a similar manner, the bank can "rollover" a loan. This measure is less straight forward to extract from loan-level data. We consider a loan "rolled-over" if for a given borrower one of its significant loans disappears from the sample (expired or concordantly ended) but the borrower limit does not decrease by more than half of the discontinued loan's amount. This implies that limits on other products were increased or new products were issued. Finally, we follow Caballero et al. (2008) and look at subsidised lending via a comparably lower interest rate. We extend this idea to account for the environment of decreasing interest rates for our sample period. Therefore, we analyse whether banks grant specific borrowers significantly greater interest rate decreases compared to their peers. We define an advantageous change in the interest rate if the decrease in a borrower's interest rate is greater than the decrease for the safest borrowers within the same sector, segment, and product type. ${ }^{7}$

These measures are very heterogeneous. A limit extension can be requested for very different purposes by very diverse borrowers. Safe borrowers might apply for more credit in order to finance projects with net positive returns. In contrast, a stressed borrower might apply for further credit when he is unable to cover due payments and expenses. However, other measures, such as

\footnotetext{
${ }^{6}$ Under Capital Requirements Regulation Article 178 (3) a) non-accrual status amounts to a default of a loan. Here, we rely on banks internal indicators of an amortisation stop which does not correlate with default, both before and after CRR/CRD IV took effect.

${ }^{7}$ An extensive description of how we measure forbearance can be found in the Appendix.
} 


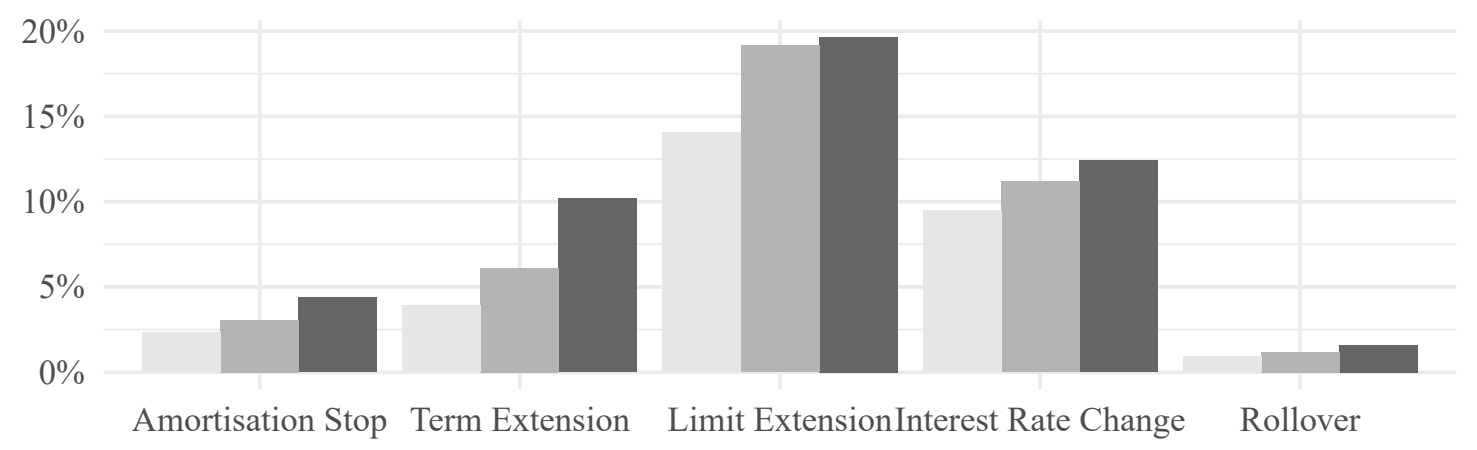

Safe Average Risky

Figure 4: Forbearance measures taken by borrower classification [\% of loans per risk class and forbearance measure].

an amortisation stop, might be the most necessary, but also the most risky, when a borrower is in distress. In order to account for this, we split borrowers in three risk categories: safe, average, and risky. ${ }^{8}$ Figure 4 shows the share per borrower rating of the different treatments across time. We find that the share of treated loans is the highest for the riskiest borrowers for every forbearance measure. The most commonly applied measure within the group of risky borrowers is a limit extension, followed by an interest rate change. A rollover and an amortisation stop are the least commonly applied measures. The fact that risky borrowers have higher shares of forborne loans goes against banks' risk aversion, but this phenomenon is intuitive when considering that borrowers in distress are most in need of additional financial support. In the following sections we will focus the banks' incentives to prevent default and test this hypothesis empirically.

\subsubsection{The Banks' Incentives and Constraints}

In the context of our research question it is important to understand how the constraints and incentives of banks influence their credit supply to the economy. Banks maximise their profits while staying solvent and holding enough liquid assets to meet their obligations. At the same time, they are subject to the capital and liquidity regulation set out in the Basel II and III framework.

\footnotetext{
${ }^{8}$ These ratings come from the banks' internal models but are homogenized by the Central Bank of Ireland by ensuring that the rating classes correspond to similar probabilities of default.
} 
Let us consider the case of a commercial loan close to default (low rating). The bank has an incentive to prevent default because of the impact on its capital ratio. NPLs have a negative impact on capital both now and in the future. First, a provisioning shortfall is deducted from Tier 1 capital $^{9}$ in case of default under the Foundation Internal Ratings Based (F-IRB) approach. ${ }^{10}$ This shortfall might occur because of the discretionary nature of provisions. Banks have an incentive to "underprovision" and only realise the loss at default. Second, a default leads to higher future provisions since these are based on historical observed default rates (see Aiyar et al. (2015) and Kang and Jassaud (2015)). International Financial Reporting Standards (IFRS) 9, in place from January 2018 on, will lead to an earlier recognition of expected losses and thereby mitigate the issue of under provisioning.

Intuitively, banks have a strong incentive to prevent this potential decrease of capital and adopt forbearance measures in order to support the borrower in difficulty. Nonetheless, forbearance measures themselves might also impact regulatory capital ratios. First, a maturity extension mechanically increases the risk weight as maturity is part of the risk weight formula. ${ }^{11}$ Second, an increase of the overall borrower limit translates directly into an increase of the exposure at default and thereby risk weighted assets. Third, reducing the interest rate will lead to lower capital because of the lower future interest earnings but risk weights are unaffected. Fourth, an amortisation stop is a temporary stop/reduction of the regular payments. The effect on capital depends on whether missed payments are repaid in full once the loan becomes amortising again. Lastly, a rollover can be seen as a maturity extension with regards to risk weights, because a considerable amount of the exposure stays on the book of the bank.

Having laid out the motivation for using forbearance measures, the question that arises is whether or not new lending is subdued because capital and other resources within the bank are allocated to forborne loans. New lending mechanically increases risk weighted assets with risk weights being dependent on observed default rates of comparable loans. This explains why, after the Global Financial Crisis, commercial lending had very high risk weights.

One could argue that these considerations only hold once the constraints become binding (low

\footnotetext{
${ }^{9}$ Excess provisions are added to Tier 2 capital.

${ }^{10}$ The majority of corporate, SME and micro SME portfolios are held under the Foundation Internal Ratings Based approach. Minor parts are accounted for using the Standardised Approach and one bank has a small part of their portfolio with the Retail Internal Ratings Based approach.

${ }^{11}$ See Capital Requirements Regulation Article 153 (1) for the F-IRB approach.
} 
capital ratios). Thus, high risk weighted capital ratios should allow the bank to focus on profitability. We argue that capital ratios alone are not sufficient to capture the pressure for banks to optimise their risk weighted assets. Credit risk poses a significant risk to capital levels as could be seen in the stress test results (see Figure 3). As the risk of a bank's loan portfolio changes over the economic cycle, seemingly prudent provisioning levels can turn out to be insufficient during an economic downturn. This uncertainty around the credit risk and its provisions casts doubt on capital levels. This effect is even more relevant if the overall quality of a bank's book is inferior. ${ }^{12}$ A deterioration of the economic environment can potentially lead to a significant average downgrade and would increase risk weighted assets and decrease capital. Therefore, the Texas Ratio defined in Section 2.1 is a more informative measure taking into account the uncertainty surrounding capital levels and credit risk.

\section{Forbearance Patterns}

\subsection{Descriptive Analysis}

Before we turn to our empirical analysis, we give some insights into our loan level data described in 2.1.1. Table 1 shows a split of the sample by rating, segment, and product type. Starting with rating, we observe not just a high share of defaulted loans ( $32.3 \%$ weighted by outstanding balance) but also a significant share of loans in the riskiest category $(26.1 \%$ weighted by outstanding balance). This supports the hypothesis that a high number of NPLs indicates an overall stressed loan portfolio. Furthermore, only $6.4 \%$ of loans weighted by outstanding balance are in the safe category. Comparing these shares by volume and number of loans, we can see that loans in the safe category are relatively smaller whereas defaulted loans are considerably larger on average. This difference is even more evident turning to the split by segment. We can see that the largest amount outstanding is towards the SME segment but the majority of loans go to micro SMEs. Even more extreme, corporate lending makes up for $18.9 \%$ of outstanding balance but only $0.3 \%$ of loans. Finally, we look at different product types where term loans represent the largest share by volume as well as number of loans. Furthermore, we see a larger amount outstanding for this

\footnotetext{
${ }^{12}$ One bank in our sample has around $50 \%$ of it's commercial loans in default throughout the sample. Accordingly, another $25 \%$ of this banks' commercial loan book is close to default.
} 
product type $(120,000 €$ on average) which is only surpassed by the "Other" category with an average loan size of $265,000 € .^{13}$

Table 2 shows how many borrowers are affected by different forbearance measures across the whole sample. 89,255 borrowers receive any kind of measure, with the most frequent being a limit extension, followed by an interest rate change. This means that more than a third of all borrowers in our sample were granted forbearance measures. This split by the individual measures confirms what we show in Figure 4: limit extension is the most popular measure, followed by interest rate changes, term extensions, an amortisation stop and finally a rollover. As even the latter has been applied to 11,353 borrowers in our sample, we argue that none of the measures are negligible.

\subsection{Empirical Approach}

In a first step, we want to estimate the probability of any or one of the five forbearance measures indexed by $i$ being applied for a given borrower $j$ in the next six months with the following logit model:

$$
\operatorname{Pr}\left(\text { forb }_{i, j, t+1}\right)=\alpha+\beta_{1} X_{l, t}+\beta_{2} T_{k, t}+\beta_{3} \text { Rating }_{l, t} * T_{k, t}+\text { forb. before }{ }_{j, t}+\text { fixed effects }+\epsilon
$$

where $X_{l, t}$ contains the time varying characteristics per loan $l$ : rating and $\ln$ (Outstanding Balance), $T_{k, t}$ corresponds to the time varying Texas Ratio of bank $k$, and forb. before $e_{j, t}$ is a dummy if borrower $j$ received any forbearance measure before. Finally, we include various fixed effects: loan age fixed effects control for the influence of the loan age on the estimated probability of forbearance, sector $\times$ time fixed effects attempt to control for the macroeconomic environment, bank $\times$ segment $\times$ product type fixed effects control for the variation between different loan products of different sizes at a given bank, and county fixed effects consider geographical variation. In order to control for other bank and time varying characteristics that might correlate with the Texas Ratio, we also include bank $\times$ time fixed effects. Once we do include bank $\times$ time fixed effects the Texas Ratio drops out of the regression and we consider the differential impact of the Texas Ratio combined with borrower riskiness. Given that borrowers do not leave the sample once they received a treatment, the dummy whether any loan by borrower $j$ was modified

\footnotetext{
${ }^{13}$ The significantly higher average in the "Other" category is due to large loans to corporates, such as syndicated loans.
} 
before $t$, forb. before $_{j, t}$, tests if it is more likely for a loan to be forborne if another measure has already been granted. Contrary to forborne loans which stay in the sample, non performing loans are excluded from the sample once default occurs. Thus, our specification does not suffer from endogeneity problems which would arise if we had NPLs on the left hand side and the Texas Ratio - including NPLs - on the right. Regarding the dependent variable, we start by testing the probability of receiving any of the five different forbearance measures: an extension in the overall credit limit or the maturity of the loan, a stop in amortisation, a change in the interest rate, or a rollover of the loan product. As a second step, we then test the specification for each measure individually in order to identify the patterns driving our results.

\subsection{Results}

\subsubsection{Overall Forbearance}

In Table 3, we show the results of our logit model regressions. From column (1) to (7) we include fixed effects and lastly the forbearance before dummy up to the full specification of equation (1). The interpretation of the results only becomes relevant once we load in at least fixed effects controlling for the demand side $($ sector $\times$ time $)$. On the other hand, the supply side fixed effects $($ bank $\times$ time $)$ are important because the Texas Ratio of a bank is likely to be correlated with other time varying bank characteristics. Nonetheless, bank $\times$ time fixed effects do not allow us to make a statement about the influence of the Texas Ratio on the probability of forbearance in absolute terms but only in relative terms. Therefore, we add fixed effects in the following order in columns $(2-6)$ : loan age, sector $\times$ time, bank $\times$ time, bank $\times$ segment $\times$ product type, and county . In order to gauge whether risky borrowers are more or less likely to receive forbearance we have to add up the difference in probabilities for the different ratings and the differential slopes with respect to the Texas Ratio and ratings. When controlling for loan age and sector $\times$ time we find that for the average Texas Ratio of $105 \%$, the probability of receiving forbearance is higher for risky borrowers than for safe borrowers. The coefficient for risky loans (having safe borrowers as the reference group) is significantly negative in column (3) but the effect is outweighed by the significantly positive interaction term for risky borrowers with the Texas Ratio (again with safe borrowers as the reference group). Therefore, we can say that a stressed borrower paired with a 


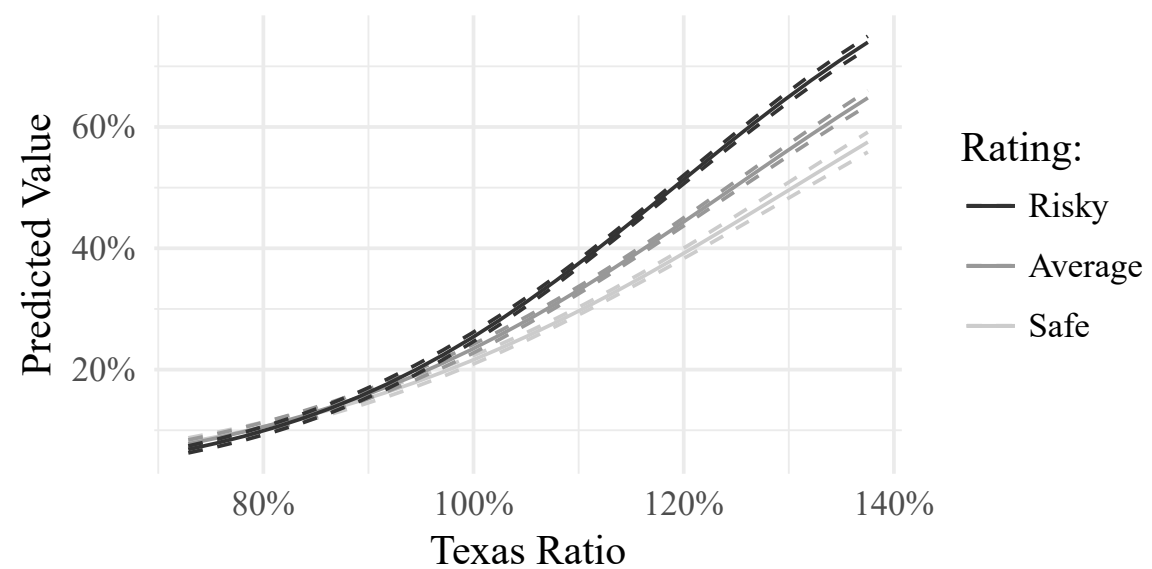

Figure 5: Predicted probability of any measure taken by borrower rating class and Texas Ratio. All other variables at mean or mode.

stressed bank has a higher probability of agreeing on forbearance than a risky borrower with a less stressed bank and a safe borrower with a stressed bank.

We present this main result in a more intuitive way in Figure 5, which is based on the regression in column (7) without bank $\times$ time fixed effects. In order to calculate the actual probabilities of receiving forbearance, we vary the Texas Ratio and keep all other values (e.g. segment, bank, $\ln$ (Outstanding Balance)) at mean or mode. We can see that for the average Texas Ratio of $105 \%$, the probability of a risky loan receiving forbearance is 5 percentage points higher than for a safe loan and at an absolute value of about $52 \%$. For a risky loan, the difference in predicted probability is around 60 percentage points between a bank with a Texas Ratio at the 95th percentile (134\%) and a bank at the 5th percentile (70\%). Given the higher Texas Ratio a representative borrower of a risky loan has a $70 \%$ probability of receiving any forbearance measure within the next six months. Therefore, we show two main results. Our first result, increasing probability of receiving a forbearance measure with decreasing borrower rating, is driven by two mechanisms: first, only borrowers in need will ask for forbearance. Secondly, borrowers have an informational advantage over their lenders which they might exploit in a situation where default is unavoidable. This strategic motive can play a role if the borrower knows that the bank believes forbearance is effective and that the bank has an incentive to help because it cannot afford to let the borrower default. Our second result is the increasing probability of receiving a forbearance measure with the increasing Texas Ratio of the lender. This is in line with the incentives for constrained banks to preserve their capital ratios by forbearing loans, outlined in Section 2.2.2. 
Furthermore, we find that larger loans are more likely to receive a forbearance measure.

Turning back to Table 3 , in column (4) we add bank $\times$ time fixed effects which are crucial to control for anything correlated with the bank's Texas Ratio. We find the interaction effect of the risky borrower's rating (with the safe rating as the reference category) and the bank's Texas Ratio to be significantly positive. In other words, for a risky borrower, the probability of receiving forbearance increases more with respect to bank level stress than for a safe borrower. One has to bear in mind that the base probability of receiving forbearance is lower but insignificant for risky borrowers as can be seen in column (4). The coefficient is significant and negative once we control for bank $\times$ segment $\times$ product type and county fixed effects. For the average value of the Texas Ratio, 105\%, the coefficient on the interaction term outweighs the difference in the baseline probability. Therefore, for the average value of the Texas Ratio and above, the probability of receiving forbearance is higher for risky borrowers compared to safe borrowers. This result is robust throughout columns (4-6).

Another way of interpreting the results is to look at odds-ratios. ${ }^{14}$ Summing up the coefficients of interest in column (7), we can say that at an average Texas Ratio of $105 \%$, the odds of a risky loan receiving forbearance are $28.5 \%$ higher than for a safe loan, ceteris paribus. With regards to the second result we compare the odds of receiving forbearance for a risky loan with a bank at times of very low and very high values of the Texas Ratio. At the 95th percentile (Texas Ratio of 134\%), the odds of receiving forbearance for a risky loan are $67 \%$ higher than at the 5 th percentile (Texas Ratio of $70 \%$ ), ceteris paribus. The other important factor in explaining the probability of receiving forbearance is if the loan already received another forbearance measure. The odds are $224 \%$ higher to receive forbearance if the borrower already received forbearance.

The previously presented results are robust given the saturation with fixed effects. Furthermore, we cluster standard errors at bank $\times$ time level to tackle the problem of heteroskedasticity. Another concern could be that at high levels of the Texas Ratios, banks have an additional incentive to forbear the most important borrowers by loan size as they are concerned about the exposure at default. Although we already control for the loan size in our regression, we conduct another robustness test, shown in Table 11 in the Appendix, where we add a double interaction effect: $\ln \left(\right.$ Outstanding Balance $\left._{l, t}\right)$ :Texas Ratio $_{k, t}$. We can see that the additional effect of the

\footnotetext{
${ }^{14}$ As we run a logit model we look at $e^{\beta}$ to get the odds-ratio.
} 
loan size at high Texas Ratios is not significant and that our main results hold.

We argue for the use of the Texas Ratio in Section 2.1 and use it for our regressions. Moreover, we test a range of bank level variables, such as: loan to deposits ratio, total gross loans, operating profit to average assets next to the Tier 1 and $\mathrm{NPL}^{15}$ ratio, in order to isolate the single most important driver of forbearance. Table 13 shows the same regression we previously interpreted for the Texas Ratio instead of the other bank level regressors. The results suggest that the NPL ratio is the most important driver of forbearance after adding loan age and sector $\times$ time fixed effects. The Tier 1 capital ratio does not appear to have a significant impact when including all the other bank level characteristics (columns 1-3). We find that the results for the Texas Ratio can be confirmed for the NPL Ratio. In column (8), we add the Tier 1 ratio interacted with the borrower rating and it turns out to be insignificant. Once we include both, the interaction of the NPL Ratio and the Tier 1 Ratio with the borrower rating in column (9), it is only the NPL Ratio interaction term that remains significant. Therefore, we conclude that the level of NPLs is driving our results when we use the Texas Ratio as a measure for bank stress in determining the granting of forbearance.

\subsubsection{Different Measures of Forbearance}

In Table 4, we look at the different forbearance measures ${ }^{16}$ individually so that the dependent variable is equal to one if a specific forbearance measure was granted within the following 6 months. For policy makers, it is indispensable to know which measure exactly the mechanism found in our previous results.

Column (1) shows the results for any forbearance measure which can be found in column (7) of Table 3 in order to contrast the individual forbearance measures results. The two main results laid out in the previous section can be confirmed for Term and Limit extensions. For these two measures, the interaction term of the borrower's rating and the bank's Texas Ratio is significantly positive (with the safe rating as the base category). The baseline probability of receiving a limit extension is significantly lower for a risky borrower than for a safe borrower. This effect is outweighed by the interaction for values of the Texas Ratio of greater than $120 \%$. One has

\footnotetext{
${ }^{15}$ The NPL Ratio is defined as: $\frac{\text { Non-Performing Loans (Impaired or } 90 \text { days past due) }}{\text { Total Loans }}$.

${ }^{16}$ See Section 2.2.1 for the definitions of each forbearance measure.
} 
to bear in mind that we define limit extension as a forbearance measure only for borrowers in distress (risky). A limit extension for a safe borrower is not necessarily forbearance but more likely growth financing. Therefore, the probability of receiving a limit extension, in the sense of growth financing, is naturally higher for a safe borrower paired with a not stressed bank, than receiving a limit extension as a forbearance measure for a risky borrower paired with a similar bank. The significantly positive coefficient on the interaction term in column (5) confirms that the probability of agreeing a limit extension increases more strongly with the Texas Ratio of the bank for risky borrowers than for safe borrowers. For term extensions the argument is the same, whereas in this case the baseline coefficient in column (3) is negative but insignificant.

Turning to the other three forbearance measures, the results differ. For an amortisation stop - column (2), an interest rate change - column (4) or a rollover - column (5) we do not find a significant influence of neither the bank's nor the borrower's risk. The interaction term for rollover and amortisation stop is positive but insignificant given our very conservative standard error clustering at bank $\times$ time level. The size of the loan is the only variable with a significant coefficient. This is to say that an amortisation stop and an interest rate change is more likely for larger loans and the contrary holds for a rollover. For all the individual forbearance measures the probability of receiving it is higher if the borrower received a forbearance before.

\subsubsection{Sequencing of forbearance measures}

Forbearance is not necessarily a one off treatment and we observe that banks and borrowers often agree to more than just one measure over time. The question arises if there is an observable pattern in the sequencing of measures. We want to check if certain types of forbearance are typically applied first while others might be predominantly used as a "measure of last resort", after other measures were deemed insufficient. A simple descriptive analysis can be found in Table 5. Among all borrowers who received more than one measure, we measure how many times each forbearance type has been applied as a first, second, or third measure. The first column describes what measures were taken first, given that two or more measures were taken for a given borrower. Because a borrower can have multiple loan products, there can be more than one forbearance measure per borrower. The distribution of measures taken first resembles that of the overall distribution presented in Figure 4 and Table 2. Limit extensions are the most common, 
followed by an interest change, whereas a rollover is the least common measure. Furthermore, out of the 244,908 borrowers in our sample, 52,255 receive two or more forbearance measures and 33,342 receive three or more. For the distribution of the measures applied second, for all cases where there were at least two measures applied, we find that limit extensions are less often applied as a second measure compared to being employed as the first measure. All other forbearance measures are employed more frequently as a second measure than as a first measure. As for the third measure we find that the relative shares differ from those of the first and second measure. A limit extension is much less likely to be taken as a third measure compared to a first and amortisation stop and interest rate changes are more likely. To conclude, a limit extension seems to be a measure more often applied at first, whereas interest rate changes and an amortisation stop become more important as a second and third measure.

\section{Effectiveness of Forbearance}

\subsection{Empirical Approach}

Having shown that banks under stress are more likely to forbear risky borrowers we now turn to the effectiveness of forbearance. This question is important for the overall economy as effective forbearance means lower default rates of firms and higher bank capital. Therefore, we estimate the probability of default for a given borrower with the following logit hazard model:

$$
\operatorname{Pr}\left(\text { Def }_{j, t}\right)=\alpha+\beta_{1} X_{l, t}+\beta_{2} F_{j, t}+\beta_{3} \text { Rating }_{l, t} * F_{j, t}+\beta_{4} \text { forb. }_{\text {before }}^{j, t}+\text { fixed effects }+\epsilon
$$

where $\operatorname{Pr}\left(\operatorname{Def}_{j, t}\right)$ is the probability of default on any loan held by borrower $j$ in different periods

in the future, $X_{l, t}$ consists of the time varying characteristics of loan $l$ : rating and $\ln$ (Outstanding Balance), $F_{j, t}$ is a dummy for (any) forbearance measure for any loan held by borrower $j$ within the last six months, and forb. before ${ }_{j, t}$ is the dummy for any previous forbearance measure towards borrower $j$. Again, we include loan age, bank $\times$ time, bank $\times$ segment $\times$ product type, and county fixed effects and we cluster standard errors at bank $\times$ time level. Sector $\times$ time fixed effects control for the macroeconomic environment in a given sector at a given point in time.

We let $\operatorname{Pr}\left(D e f_{j}\right)$ vary over periods in order to analyse the timing of default. Given that only 
forbearance measures to risky borrowers should be of concern, we look at $\beta_{3}$ where the $R a t i n g_{l, t}$ is Risky. If forbearance was effective, this should lead to a lower probability of default of the borrower, hence $\beta_{3}$ would be negative for any time period. However, if forbearance is just used to conceal "short-term" threats to a bank's balance sheet, $\beta_{3}$ might be significant only in the short term, i.e. lowering the probability of default for short periods.

\subsection{Results}

The regression results of the logit model can be found in Table 6. We first analyse if the granting of any forbearance measure is associated with a lower probability of default in the future (infinite horizon). As the ratings are defined by the ex-ante probability of default, the increasing coefficients with riskiness across all columns are reassuring. However, even controlling for the rating, the interaction of the dummy for any forbearance with the rating is positive for all ratings when controlling at least for loan age and sector $\times$ time. In other words, a risky borrower who received forbearance is more likely to default than a risky borrower who did not receive forbearance. This result is robust when loading in more fixed effects.

We suggest that these results could be driven by two different mechanisms. First, a selection bias might cause a bank to choose to give forbearance to the "worst" borrowers (closest to default) within the group of risky borrowers in an attempt to prevent default where it is most likely. Secondly, borrowers might act strategically and demand forbearance knowing that they are going to default even with forbearance. The intuition is that it might be profitable for firms to keep business alive even just for a limited period of time. We cannot disentangle these two effects. However, we can conclude that they outweigh the positive impact of forbearance as a financial support for struggling borrowers in order to prevent default. Using the regression results in column (6), with all fixed effects loaded in, we find that the odds of default for a borrower having received any forbearance measure in the last six months are $20 \%$ higher than if the borrower was not treated. In column (7), we add the forbearance before dummy but we find no significant effect for this variable. Outstanding balance has a significantly positive coefficient, which means that larger loans are more likely to default.

In Figure 6, we show our result graphically. The graph shows the probability of default for 


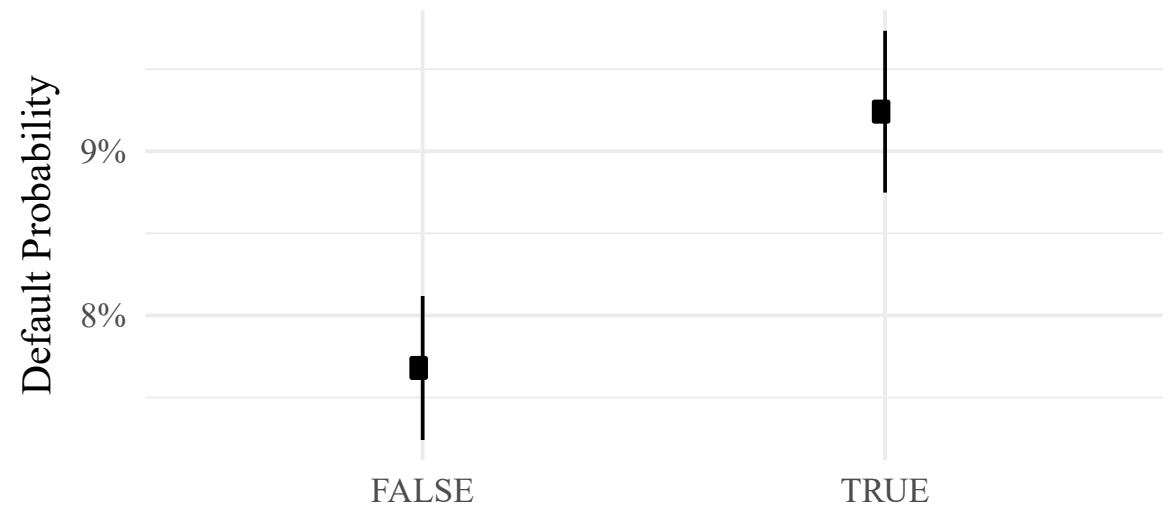

Any measure

Figure 6: Predicted probability of default for a risky loan, depending on any measure being taken. All other variables at mean or mode.

Source: Author's Calculations; Data: CBI

risky borrowers who received a forbearance measure and those who did not receive a measure in time $t$. In order to calculate the actual probabilities, we keep all variables at mean or mode and change only the dummy for any measure. If no measure was taken during the last six months, the probability of default is around $8.7 \%$. The probability for a risky borrower who received forbearance in the last six months is significantly higher at around $9.25 \%$. The default probabilities are significantly lower if we do not condition the results on the riskiness of the borrower. Figure 8 in the appendix shows the probabilities ranging from $1.4 \%$ to $1.8 \%$ for the average borrower.

Again, it is crucial for policy makers to know which measures of forbearance are associated with a higher probability of default. In Table 7 , we can see the results for the different measures. In column (1), we see the result for any measure as a benchmark for the results of the individual measures. All regressions control for the full set of fixed effects. The findings outlined regarding the negative impact of any measure on subsequent default are confirmed for term extensions, interest rate changes, and amortisation stops. The probability of default is higher given that a risky borrower has received these three different forbearance measures. The overall finding cannot be confirmed for limit extensions or rollovers. For these two, the coefficients are negative but insignificant. However, only a negative coefficient could be interpreted as a positive effect of this forbearance measure. Therefore, also for those measures, we cannot show that they effectively lower default rates for stressed borrowers. 
In a last step, we want to analyse the timing of default. We just showed that $\beta_{3}$ is positive for Rating - Risky $y_{l, t} * F_{j, t}$ which means that risky borrowers who received forbearance were subsequently more likely to default than other risky borrowers. This would be an additional loss (of the forbearance) for the bank and would not be in line with banks' profit optimizing behaviour. However, if forbearance is just used to conceal (short-term) threats to a bank's balance sheet, $\beta_{3}$ might be significant only in the short term, i.e. lowering the probability of default for short periods.

Comparing Table 6 and Table 8, where the dependent variables are Probability of default in any period in the future and Probability of default in the next six months we can evaluate the effectiveness in the short and long run. Again, we focus on $R i s k y_{l, t} * F_{j, t}$ where we see that overall, the coefficient is significantly positive for both specifications, i.e. forbearance is associated with a higher probability of default both in the short and in the long term.

However, looking at measures individually reveals surprising results. Besides the importance for policy, we argue that the different measures also impose different risks for banks. E.g. if a banks grants a limit extension, it increases its exposure and would therefore suffer a greater loss in the case of default. On the other hand, a bank increases its risk relatively less through a small change in the interest rate or a term extension. In line with this reasoning, we find the coefficient on Limit Extension to be significantly negative in the short term in Table 9 while it is insignificant in the long term (Table 7). As Limit Extension is the most common measure of forbearance this lets us conclude that the most common form of forbearance decreases the probability of default in the short term but remains uncorrelated to default for longer horizons and is therefore not effective in ultimately preventing default. In a final specification in Table 12, we show the effectiveness for every period after each forbearance measure was granted for all risky borrowers. We can see that Limit Extensions are significantly negatively related with defaults up to two periods after the measure was taken while borrowers are equally as probably to default as borrowers within the same risk category thereafter. On the other hand, Amortisation Stops are always associated with higher probabilities of default at any point in the future. This could be due to a "selection bias" where this measure is only given to the riskiest borrowers among those with a "risky" rating. This reasoning is in line with our findings in section 3.3.3 where we highlight that Amortisation Stop is relatively more often applied as a second or third measure 
and could therefore be interpreted as a "measure of last resort".

\section{Correlation with new Lending}

\subsection{Empirical Approach}

Existing literature shows that when stressed banks keep relationships with risky borrowers alive, they issue significantly lower volumes of new lending compared with their peers (e.g. Acharya et al. (2019); Caballero et al. (2008)). This literature strongly emphasises the negative real effects this behaviour can have for the economy. The presence of zombie firms was found to depress job creation, deter the entry of healthy firms, and to decrease employment and investment levels in healthy firms (Giannetti and Simonov, 2013).

The empirical evidence from this literature suggests a relationship between credit supply and lower volumes of new credit. In Figure 7, we analyse seasonally adjusted ${ }^{17}$ quarterly new lending to Irish firms. While Irish banks were under stress due to their high NPL levels, their new lending to the SME sector was subdued. Accornero et al. (2017) also find a negative relationship of outstanding loans and NPLs but show that this was due to constrained credit demand for the Italian case. In order to shed more light on this mechanism for Ireland, we look at survey data on SME credit applications during that time. ${ }^{18}$ The dotted (dashed) line in Figure 7 shows the application (rejection) rate for Irish SMEs over time. The application rate for new products and thereby demand for new credit was high in 2012 and continuously dropped throughout the sample. The coincidence of the period of low new lending volumes and high credit demand suggests that the low volumes were driven by banks credit supply. The dashed line confirms the high rejection rate for new product applications around the time of low new lending volumes. In our empirical analysis, we want to see if this is correlated with forbearance patterns which might tie up capital so that supply for new loans remains suppressed.

In the following, we test this correlation of forbearance and new lending for Ireland. First, we set

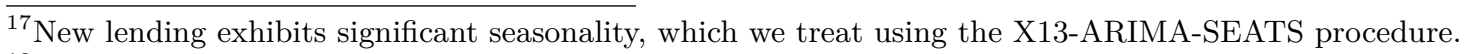

${ }^{18}$ We obtain these data from the RedC Reports on SME lending provided by the Department of Finance of Ireland. As SMEs are by far the largest borrower group, we argue that it is representative to look at this group in order to get an overview of the lending market.
} 


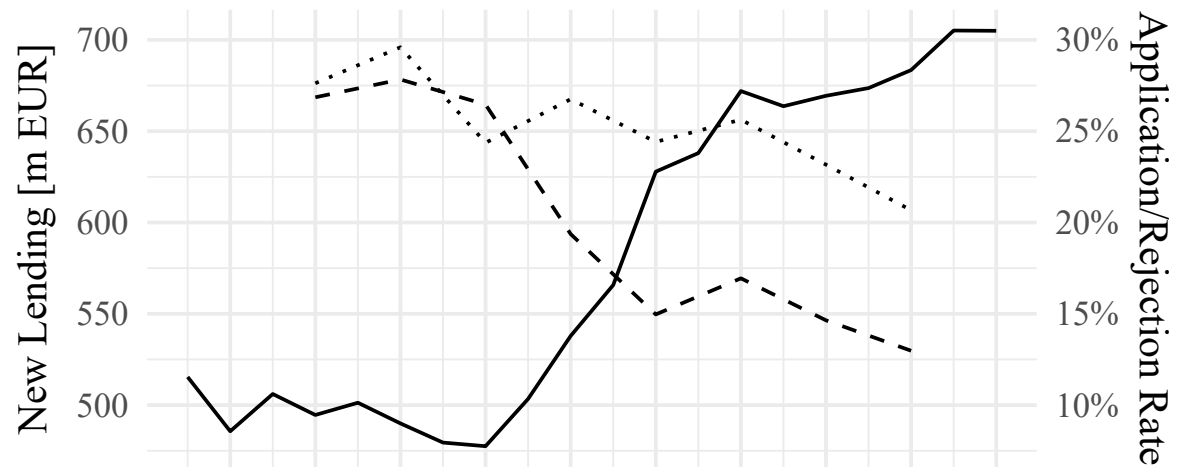

11Q3 12Q1 12Q3 13Q1 13Q3 14Q1 14Q3 15Q1 15Q3 16Q1 16Q3

… Applications — New Lending - - Rejections

Figure 7: The left y-axis shows the quarterly new lending to Irish SMEs (seasonally adjusted in $\mathrm{m}$ EUR). Source: Author's Calculations; Data: CBI

The right y-axis shows application rate for new products (\% of firms) and rejection rate for new products (\% of applications) for Irish SMEs. Data: RED-C SME Market Report

up buckets of borrowers, $b$, by bank, segment, time, and county because we suggest that lending decisions are made separately for these groups. Then, we estimate the following OLS regression:

$$
\text { Share }(\text { New Lending })_{b, t}=\alpha+\text { Share }(\text { Forbearance })_{b, t-1}+\text { fixed effects }+\epsilon
$$

where Share (New Lending $)_{b, t}$ is the sum of lending to new borrowers over the total lending in bucket $b$ in time $t$ and Share(Forbearance $)_{b, t-1}$ is the sum of loans to forborne borrowers over the total lending in $t-1$ in bucket $b$. Again, we add fixed effects to control for the macroeconomic environment (county $\times$ time) and variation between banks (bank), and between banks over time $($ bank $\times$ time $)$.

\subsection{Results}

The results in Table 10 confirm a negative correlation between forbearance and new lending in the same bucket and across all specifications. This means that the higher the share of forbearance within a certain segment and county by a specific bank, the lower the share of new loans. This result holds when saturating the regression with fixed effects (see columns 1-4). In terms of magnitude, a $1 \%$ higher share of forborne loans is correlated with a $0.076 \%$ lower share of new lending, as can be seen in our most conservative specification in column (4). 
We test the robustness of this result in two ways: first, we use contemporaneous new lending

in column (5). As our unit of time is relatively large (six months) the decision to "substitute" new lending with forbearance could happen within the same time period. Second, instead of using the share of new lending and forbearance, we use the natural logarithm of new lending and forbearance instead of shares in column (6). However, for both robustness checks, results remain highly significant even in our most conservative specification. Combining this with our previous results and the literature we can suggest that forbearance - which occurs mostly for risky borrowers - is a trade-off for new loans, which are potentially safer.

\section{Conclusion}

In this paper, we analysed the forbearance patterns of stressed banks in the post-crisis period. More specifically, our analysis presents five measures: an extension in the credit limit or maturity, a pause in amortisation, a comparably lower interest rate change, and a rollover of a loan product. We find that risky borrowers are more likely to receive a limit or maturity extension when banks are facing high levels of NPLs relative to their capitalisation and provisions. As a second step, we evaluate the effectiveness of this practice. Using a logit-hazard model, we find that a limit extension is effective in reducing the probability of default up to one year. For longer horizons and other forbearance measures we find a higher probability of default of the risky borrower. While we cannot conclude that the forbearance measures themselves caused defaults, we argue that credit might have been misallocated to the weakest borrowers which were subsequently not "rescued" from default. In the last part of our empirical analysis, we show that banks with a high share of forborne loans issue lower volumes of new credit. This could result in tighter financial conditions for new firms which might potentially be more productive.

Our analysis highlights the importance of the health banks' loan books. While banks can be well-capitalised on paper, they might be under pressure by high levels of non-performing loans on their balance sheets. We suggest that banks have an incentive to forbear loans and avoid categorizing them as non-performing, and offer an explanation through the regulatory framework. This is crucial for policy makers as uncertainty about the real quality of the loan book, if widespread in the economy, can lead to systemic risk and undermine trust in the banking sector's 
solvency.

Although it is too early to analyze the effectiveness of forbearance during the current Covid-19 pandemic, our findings - especially on the effectiveness of forbearance - can help policy makers to optimize the surveillance of the banking sector in a future recovery phase. Due to the high uncertainty in the initial months of the pandemic, the implementation of broad-based forbearance measures to carry agents through the liquidity shortfall was justified. However, as disentangling illiquidity from insolvency becomes easier, our findings may help policy makers to shape a more targeted approach in later phases of the crisis. 


\section{References}

Accornero, M., P. Alessandri, L. Carpinelli, and A. M. Sorrentino (2017): “Nonperforming loans and the supply of bank credit: evidence from Italy," Bank of Italy Working Paper.

Acharya, V., T. Eisert, C. Eufinger, And C. Hirsch (2018): "Same story, different place?: Post-crisis recapitalization of banks in Japan and Europe," Finance and Investment: The European Case, 137-147.

Acharya, V. V., T. Eisert, C. Eufinger, And C. Hirsch (2019): "Whatever It Takes: The Real Effects of Unconventional Monetary Policy," The Review of Financial Studies, 32, 3366-3411.

Aiyar, S., A. Banerji, B. Barkbu, W. B. W., P. Berkmen, J. Bluedorn, J. Garrido, A. Jobst, J. John, K. Kang, T. Kinda, H. L. H., Y. Liu, D. Monaghan, M. M. M., S. Saksonovs, H. Schoelermann, And T. Wu (2015): "Euro Area Policies: Selected Issues," International Monetary Fund.

Albertazzi, U. And D. J. Marchetti (2010): "Credit supply, flight to quality and evergreening: an analysis of bank-firm relationships after Lehman," Bank of Italy Working Paper, 756.

Bonaccorsi Di PATti, E. AND A. KAShyAP (2017): "Which Banks recover from large adverse Shocks?" NBER Working Paper.

Caballero, R. J., T. Hoshi, and A. K. Kashyap (2008): "Zombie lending and depressed restructuring in Japan," American Economic Review, 98, 1943-77.

Diamond, D. W. And R. G. Rajan (2011): "Fear of Fire Sales, Illiquidity Seeking, and Credit Freezes," The Quarterly Journal of Economics, 126, 557-591.

EBA (2016a): "EBA Risk Dashboard Q3 2016," https://www.eba.europa.eu/-/ eba-updated-risk-dashboard-shows-that-elevated-npls-and-a-high-cost-base -pose-a-significant-profitability-challenge-for-eu-banks?doAsGroupId=10180, $07 / 2016$.

- (2016b): "EBA Stress Test 2016," http://www.eba.europa.eu/ risk-analysis-and-data/eu-wide-stress-testing, 07/2016.

Eisfeldt, A. L. AND A. A. RAmpini (2008): "Managerial incentives, capital reallocation, and the business cycle," Journal of Financial Economics, 87, 177-199.

Giannetti, M. And A. Simonov (2013): "On the Real Effects of Bank Bailouts: Micro Evidence from Japan," American Economic Journal: Macroeconomics, 5, 135-67. 
Homar, T., H. Kick, And C. Salleo (2015): "What drives forbearance - Evidence from the ECB Comprehensive Assessment," ECB Working Paper.

Honohan, P. (2010): "The Irish Banking Crisis: Regulatory and Financial Stability Policy 2003-2008," Report of the Commission of Investigation into the Banking Sector in Ireland.

Huizinga, H. And L. Laeven (2012): "Bank valuation and accounting discretion during a financial crisis," Journal of Financial Economics, 106, 614-634.

IMF (2016): "IMF Country Report No. 16/258," https://www.imf .org/external/pubs/cat/ longres. aspx?sk=44305.0, 07/2016.

KAnG, K. And N. Jassaud (2015): "A Strategy for Developing a Market for Nonperforming Loans in Italy," IMF Working Paper, 15/24.

Keuschnigg, C. And M. Kogler (2017): "Schumpeterian Banks: Credit Reallocation and Capital Requirements," CEPR Working Paper, 12443.

Lane, P. R. (2011): "The Irish Crisis," The Euro Area and The Financial Crisis, 59-80.

Peek, J. And E. S. Rosengren (2005): "Unnatural Selection: Perverse Incentives and the Misallocation of Credit in Japan," American Economic Review, 95, 1144-1166.

Schivardi, F., E. Sette, and G. Tabellini (2017): "Credit Misallocation During the European Financial Crisis," SEP Working Papers.

Sekine, T., K. Kobayashi, and Y. Saita (2003): "Forebearance lending: The case of Japanese firms," Monetary and Economic Studies, 21, 69-92.

Watanabe, W. (2010): "Does a large loss of bank capital cause Evergreening? Evidence from Japan," Journal of the Japanese and International Economies, 24, 116-136.

Zhang, D., J. Cai, D. G. Dickinson, And A. Kutan (2016): "Non-performing loans, moral hazard and regulation of the Chinese commercial banking system," Journal of Banking and Finance, 63, 48-60. 


\section{Tables}

Table 1: Summary statistics by segment, rating, and product type

\begin{tabular}{lcc}
\hline \hline Split by: & $\begin{array}{c}\text { Sample share by } \\
\text { outstanding } \\
\text { balance }\end{array}$ & $\begin{array}{c}\text { Sample share by } \\
\text { number of loans }\end{array}$ \\
\hline Rating & & \\
\hline Safe & $6.4 \%$ & $8.7 \%$ \\
Average & $35.2 \%$ & $40.0 \%$ \\
Risky & $26.1 \%$ & $32.5 \%$ \\
Default & $32.3 \%$ & $18.9 \%$ \\
\hline Segment & & \\
\hline Corporate & $18.9 \%$ & $0.3 \%$ \\
SME & $61.6 \%$ & $30.7 \%$ \\
Micro SME & $19.4 \%$ & $69.0 \%$ \\
\hline Product Type & & \\
\hline Term Loan & $81.8 \%$ & $49.6 \%$ \\
Overdraft & $6.9 \%$ & $34.3 \%$ \\
Leasing/Hire Purchase & $4.6 \%$ & $14.3 \%$ \\
Other & $6.7 \%$ & $1.7 \%$ \\
\hline
\end{tabular}

Note: Ratings are based on underlying ex-ante probabilities of default for individual loans, segments relate to the size of the firm, and product type describes the type of loan held by the borrower. These summary statistics are averages over 1,686,325 observations (loan $\times$ time) held by 244,908 borrowers in our sample.

Table 2: Number of borrowers who received a forbearance measure

\begin{tabular}{lc}
\hline \hline & Number of borrowers \\
\hline Rollover & 11,353 \\
Amortisation Stop & 14,087 \\
Term Extension & 17,377 \\
Interest Rate Change & 27,837 \\
Limit Extension & 69,209 \\
Any measure & 89,255 \\
\hline All borrowers & 244,908 \\
\hline
\end{tabular}

Note: The numbers presented here are across time, which means that borrowers can obtain more than one measure. 
Table 3: Logit regression: Probability of application of any forbearance measure - Texas Ratio

\begin{tabular}{|c|c|c|c|c|c|c|c|}
\hline & \multicolumn{7}{|c|}{ Dependent variable: } \\
\hline & \multicolumn{7}{|c|}{ Any measure $_{j}$} \\
\hline & $(1)$ & $(2)$ & $(3)$ & $(4)$ & $(5)$ & $(6)$ & $(7)$ \\
\hline Rating - Average $e_{l}$ & $\begin{array}{c}-0.152 \\
(0.296)\end{array}$ & $\begin{array}{c}-0.136 \\
(0.295)\end{array}$ & $\begin{array}{c}-0.202 \\
(0.237)\end{array}$ & $\begin{array}{c}0.029 \\
(0.120)\end{array}$ & $\begin{array}{c}-0.153 \\
(0.113)\end{array}$ & $\begin{array}{c}-0.162 \\
(0.112)\end{array}$ & $\begin{array}{c}-0.094 \\
(0.172)\end{array}$ \\
\hline Rating - Risky $l$ & $\begin{array}{c}-0.843 \\
(0.585)\end{array}$ & $\begin{array}{r}-0.856 \\
(0.589)\end{array}$ & $\begin{array}{c}-0.887^{* * *} \\
(0.338)\end{array}$ & $\begin{array}{c}-0.408 \\
(0.268)\end{array}$ & $\begin{array}{c}-0.565^{* *} \\
(0.263)\end{array}$ & $\begin{array}{c}-0.578^{* *} \\
(0.263)\end{array}$ & $\begin{array}{c}-0.589^{* *} \\
(0.273)\end{array}$ \\
\hline $\ln \left(\right.$ Outstanding Balance $\left._{l}\right)$ & $\begin{array}{l}0.218^{* * *} \\
(0.012)\end{array}$ & $\begin{array}{l}0.213^{* * *} \\
(0.012)\end{array}$ & $\begin{array}{l}0.207^{* * *} \\
(0.013)\end{array}$ & $\begin{array}{l}0.212^{* * *} \\
(0.013)\end{array}$ & $\begin{array}{l}0.132^{* * *} \\
(0.009)\end{array}$ & $\begin{array}{l}0.130^{* * *} \\
(0.008)\end{array}$ & $\begin{array}{l}0.096^{* * *} \\
(0.009)\end{array}$ \\
\hline Texas Ratio $_{k}$ & $\begin{array}{c}-0.014 \\
(0.009)\end{array}$ & $\begin{array}{c}-0.014 \\
(0.009)\end{array}$ & $\begin{array}{r}-0.052^{*} \\
(0.027)\end{array}$ & & & & \\
\hline Rating - Average $l:$ Texas $^{\text {Ratio }} k$ & $\begin{array}{c}0.009 \\
(0.008)\end{array}$ & $\begin{array}{c}0.009 \\
(0.008)\end{array}$ & $\begin{array}{l}0.012^{* * *} \\
(0.004)\end{array}$ & $\begin{array}{c}0.001 \\
(0.001)\end{array}$ & $\begin{array}{l}0.003^{* *} \\
(0.001)\end{array}$ & $\begin{array}{l}0.003^{* *} \\
(0.001)\end{array}$ & $\begin{array}{c}0.002 \\
(0.002)\end{array}$ \\
\hline Rating - Risky $l$ :Texas Ratio $k$ & $\begin{array}{c}0.014 \\
(0.009)\end{array}$ & $\begin{array}{c}0.014 \\
(0.009)\end{array}$ & $\begin{array}{l}0.017^{* * *} \\
(0.005)\end{array}$ & $\begin{array}{c}0.006^{*} \\
(0.003)\end{array}$ & $\begin{array}{l}0.008^{* * *} \\
(0.003)\end{array}$ & $\begin{array}{l}0.008^{* * *} \\
(0.003)\end{array}$ & $\begin{array}{l}0.008^{* *} \\
(0.003)\end{array}$ \\
\hline Loans/Deposits $k$ & $\begin{array}{c}0.016 \\
(0.021)\end{array}$ & $\begin{array}{c}0.017 \\
(0.021)\end{array}$ & $\begin{array}{c}-0.019 \\
(0.014)\end{array}$ & & & & \\
\hline Rating - Average ${ }_{l}:$ Loans/Deposits $k$ & $\begin{array}{c}-0.011 \\
(0.019)\end{array}$ & $\begin{array}{c}-0.012 \\
(0.019)\end{array}$ & $\begin{array}{c}0.006 \\
(0.008)\end{array}$ & & & & \\
\hline Rating - Risky ${ }_{l}$ :Loans/Deposits $k$ & $\begin{array}{c}-0.022 \\
(0.020)\end{array}$ & $\begin{array}{c}-0.022 \\
(0.020)\end{array}$ & $\begin{array}{c}-0.004 \\
(0.009)\end{array}$ & & & & \\
\hline $\ln ($ Gross Loans $k)$ & $\begin{array}{c}1.655 \\
(1.895)\end{array}$ & $\begin{array}{c}1.773 \\
(1.899)\end{array}$ & $\begin{array}{c}0.126 \\
(1.515)\end{array}$ & & & & \\
\hline Rating - Average $l: \ln \left(\right.$ Gross Loans $\left._{k}\right)$ & $\begin{array}{c}-1.247 \\
(1.731)\end{array}$ & $\begin{array}{c}-1.351 \\
(1.735)\end{array}$ & $\begin{array}{r}-1.803^{*} \\
(1.031)\end{array}$ & & & & \\
\hline Rating - Risky $l: \ln \left(\right.$ Gross Loans $\left._{k}\right)$ & $\begin{array}{c}-2.099 \\
(1.787)\end{array}$ & $\begin{array}{c}-2.246 \\
(1.798)\end{array}$ & $\begin{array}{c}-2.222^{* *} \\
(1.107)\end{array}$ & & & & \\
\hline Op. Profit/Avg. Assets $k$ & $\begin{array}{c}0.404 \\
(0.272)\end{array}$ & $\begin{array}{c}0.412 \\
(0.270)\end{array}$ & $\begin{array}{l}1.509^{* *} \\
(0.719)\end{array}$ & & & & \\
\hline Rating - Average $l$ :Op. Profit/Avg. Assets $k$ & $\begin{array}{c}-0.186 \\
(0.224)\end{array}$ & $\begin{array}{c}-0.194 \\
(0.224)\end{array}$ & $\begin{array}{c}0.028 \\
(0.094)\end{array}$ & & & & \\
\hline Rating - Risky ${ }_{l}$ :Op. Profit/Avg. Assets $k$ & $\begin{array}{r}-0.473^{*} \\
(0.263)\end{array}$ & $\begin{array}{r}-0.490^{*} \\
(0.264)\end{array}$ & $\begin{array}{c}-0.178 \\
(0.118)\end{array}$ & & & & \\
\hline Forbearance Before $_{j}$ & & & & & & & $\begin{array}{l}1.178^{* * *} \\
(0.098)\end{array}$ \\
\hline Fixed Effects: & & & & & & & \\
\hline Loan age & & Yes & Yes & Yes & Yes & Yes & Yes \\
\hline Sector $\mathrm{x}$ Time & & & Yes & Yes & Yes & Yes & Yes \\
\hline Bank x Time & & & & Yes & Yes & Yes & Yes \\
\hline Bank x Segment x Prod. Type & & & & & Yes & Yes & Yes \\
\hline County & & & & & & Yes & Yes \\
\hline Observations & $1,393,284$ & $1,393,284$ & $1,393,284$ & $1,393,284$ & $1,393,284$ & $1,393,284$ & $1,324,317$ \\
\hline
\end{tabular}

Note: Logit Regression with standard errors clustered at Bank $x$ Time level. The dependent variable is the probability of receiving forbearance in $t+1$ whereas the independent variables are measured in $t$. A Texas Ratio of $100 \%$ corresponds to a value of 100 in the regression. We split the borrowers in Safe, Average and Risky based on their ex-ante probability of default. Forbearance Before is a dummy which is one if a borrower has ever received forberance before $t+1$. Significance levels: ${ }^{*} p<0.1 ;{ }^{* *} p<0.05 ;{ }^{* * *} p<0.01$ 
Table 4: Logit regression: Probabilities of different measures being applied, taking into account prior forbearance

\begin{tabular}{|c|c|c|c|c|c|c|}
\hline \multirow[b]{2}{*}{ Measure $_{i}$ : } & \multicolumn{6}{|c|}{ Dependent variable: } \\
\hline & $\begin{array}{c}\text { Any } \\
\text { measure }_{j} \\
(1) \\
\end{array}$ & $\begin{array}{c}\text { Amortisation } \\
\text { Stop }_{j} \\
(2) \\
\end{array}$ & $\begin{array}{c}\text { Term } \\
\text { Extension }_{j} \\
(3) \\
\end{array}$ & $\begin{array}{c}\text { Interest } \\
\text { Rate } \\
\text { Change }_{j} \\
(4) \\
\end{array}$ & $\begin{array}{c}\text { Limit }_{\text {Extension }_{j}} \\
(5) \\
\end{array}$ & $\begin{array}{c}\text { Rollover }_{j} \\
(6) \\
\end{array}$ \\
\hline Rating Average $_{l}$ & $\begin{array}{c}-0.094 \\
(0.172)\end{array}$ & $\begin{array}{c}0.099 \\
(0.665)\end{array}$ & $\begin{array}{c}-0.614 \\
(0.473)\end{array}$ & $\begin{array}{c}0.050 \\
(0.193)\end{array}$ & $\begin{array}{c}-0.184^{*} \\
(0.103)\end{array}$ & $\begin{array}{c}-0.445 \\
(0.386)\end{array}$ \\
\hline Rating Risky ${ }_{l}$ & $\begin{array}{c}-0.589^{* *} \\
(0.273)\end{array}$ & $\begin{array}{c}0.851 \\
(0.592)\end{array}$ & $\begin{array}{c}-0.512 \\
(0.470)\end{array}$ & $\begin{array}{c}0.073 \\
(0.331)\end{array}$ & $\begin{array}{c}-0.483^{* *} \\
(0.225)\end{array}$ & $\begin{array}{c}-0.102 \\
(0.441)\end{array}$ \\
\hline $\ln \left(\right.$ Outstanding Balance $\left._{l}\right)$ & $\begin{array}{l}0.096^{* * *} \\
(0.009)\end{array}$ & $\begin{array}{c}0.030^{*} \\
(0.015)\end{array}$ & $\begin{array}{c}0.029 \\
(0.021)\end{array}$ & $\begin{array}{l}0.240^{* * *} \\
(0.025)\end{array}$ & $\begin{array}{c}0.008 \\
(0.008)\end{array}$ & $\begin{array}{c}-0.112^{* * *} \\
(0.014)\end{array}$ \\
\hline Rating Average $l$ :Texas Ratio ${ }_{k}$ & $\begin{array}{c}0.002 \\
(0.002)\end{array}$ & $\begin{array}{c}0.001 \\
(0.006)\end{array}$ & $\begin{array}{l}0.009^{* *} \\
(0.005)\end{array}$ & $\begin{array}{c}-0.001 \\
(0.002)\end{array}$ & $\begin{array}{l}0.003^{* * *} \\
(0.001)\end{array}$ & $\begin{array}{c}0.001 \\
(0.004)\end{array}$ \\
\hline Rating Risky $_{l}:$ Texas Ratio $_{k}$ & $\begin{array}{l}0.008^{* *} \\
(0.003)\end{array}$ & $\begin{array}{c}0.0005 \\
(0.006)\end{array}$ & $\begin{array}{l}0.014^{* * *} \\
(0.005)\end{array}$ & $\begin{array}{c}-0.002 \\
(0.004)\end{array}$ & $\begin{array}{c}0.004^{*} \\
(0.002)\end{array}$ & $\begin{array}{c}0.0005 \\
(0.005)\end{array}$ \\
\hline Forbearance Before $_{j}$ & $\begin{array}{l}1.178^{* * *} \\
(0.098)\end{array}$ & $\begin{array}{l}1.184^{* * *} \\
(0.186)\end{array}$ & $\begin{array}{l}0.676^{* * *} \\
(0.146)\end{array}$ & $\begin{array}{l}1.667^{* * *} \\
(0.226)\end{array}$ & $\begin{array}{l}0.728^{* * *} \\
(0.085)\end{array}$ & $\begin{array}{l}0.291^{* * *} \\
(0.111)\end{array}$ \\
\hline Fixed Effects: & & & & & & \\
\hline $\begin{array}{l}\text { Loan age } \\
\text { Sector } \mathrm{x} \text { Time }\end{array}$ & $\begin{array}{l}\text { Yes } \\
\text { Yes }\end{array}$ & $\begin{array}{l}\text { Yes } \\
\text { Yes }\end{array}$ & $\begin{array}{l}\text { Yes } \\
\text { Yes }\end{array}$ & $\begin{array}{l}\text { Yes } \\
\text { Yes }\end{array}$ & $\begin{array}{l}\text { Yes } \\
\text { Yes }\end{array}$ & $\begin{array}{l}\text { Yes } \\
\text { Yes }\end{array}$ \\
\hline Bank x Time & Yes & Yes & Yes & Yes & Yes & Yes \\
\hline Bank x Segment x Prod. Type & Yes & Yes & Yes & Yes & Yes & Yes \\
\hline County & Yes & Yes & Yes & Yes & Yes & Yes \\
\hline Observations & $1,324,317$ & $1,321,654$ & 972,779 & $1,304,003$ & $1,181,047$ & $1,285,117$ \\
\hline
\end{tabular}

Note: Logit Regression with standard errors clustered at Bank $x$ Time level. The dependent variable is the probability of receiving a specific forbearance measure $i$ in $t+1$ whereas the independent variables are measured in $t$. A Texas Ratio of $100 \%$ corresponds to a value of 100 in the regression. We split the borrowers in Safe, Average and Risky based on their ex-ante probability of default. Forbearance Before is a dummy which is one if a borrower has ever received forbearance before $t+1$. Significance levels: ${ }^{*} p<0.1 ;{ }^{* *} p<0.05 ;{ }^{* * *} p<0.01$

Table 5: Number of occurrence of each measure granted in a sequence of measures.

\begin{tabular}{lrrrrrr}
\hline & \multicolumn{2}{c}{$\begin{array}{c}\text { First Measure } \\
\text { of } 2 \text { or more }\end{array}$} & \multicolumn{2}{c}{$\begin{array}{c}\text { Second Measure } \\
\text { of } 2 \text { or more }\end{array}$} & \multicolumn{2}{c}{$\begin{array}{c}\text { Third Measure } \\
\text { of 3 or more }\end{array}$} \\
\hline Term Extension & 5,370 & $8.6 \%$ & 6,506 & $10.4 \%$ & 3,598 & $8.8 \%$ \\
Limit Extension & 34,201 & $55.1 \%$ & 32,109 & $51.1 \%$ & 19,860 & $48.6 \%$ \\
Interest Rate Change & 14,271 & $23.0 \%$ & 15,119 & $24.1 \%$ & 11,186 & $27.4 \%$ \\
Amortisation Stop & 5,102 & $8.2 \%$ & 5,687 & $9.0 \%$ & 4,341 & $10.6 \%$ \\
Rollover & 3,179 & $5.1 \%$ & 3,438 & $5.5 \%$ & 1,840 & $4.5 \%$ \\
\hline Total number of borrowers & 52,255 & \multicolumn{2}{c}{52,255} & 33,342 \\
\hline \hline
\end{tabular}

Note: Among all borrowers who received more than one measure, we measure how many times each forbearance type has been applied as a first, second, or a third measure. 
Table 6: Logit regression: Probability of default for any loan by borrower - Influence of any measure taken by borrower

\begin{tabular}{|c|c|c|c|c|c|c|c|}
\hline & \multicolumn{7}{|c|}{ Dependent variable: } \\
\hline & \multicolumn{7}{|c|}{ Probability of Default $_{j}$} \\
\hline & $(1)$ & $(2)$ & $(3)$ & $(4)$ & $(5)$ & $(6)$ & $(7)$ \\
\hline Rating Average $l$ & $\begin{array}{l}1.199^{* * *} \\
(0.181)\end{array}$ & $\begin{array}{l}1.204^{* * *} \\
(0.185)\end{array}$ & $\begin{array}{l}1.370^{* * *} \\
(0.111)\end{array}$ & $\begin{array}{l}1.380^{* * *} \\
(0.116)\end{array}$ & $\begin{array}{l}1.280^{* * *} \\
(0.118)\end{array}$ & $\begin{array}{l}1.281^{* * *} \\
(0.118)\end{array}$ & $\begin{array}{l}1.281^{* * *} \\
(0.118)\end{array}$ \\
\hline Rating Risky ${ }_{l}$ & $\begin{array}{l}2.895^{* * *} \\
(0.291)\end{array}$ & $\begin{array}{l}2.898^{* * *} \\
(0.286)\end{array}$ & $\begin{array}{l}3.001^{* * *} \\
(0.151)\end{array}$ & $\begin{array}{l}3.061^{* * *} \\
(0.152)\end{array}$ & $\begin{array}{l}3.010^{* * *} \\
(0.155)\end{array}$ & $\begin{array}{l}3.010^{* * *} \\
(0.155)\end{array}$ & $\begin{array}{l}3.010^{* * *} \\
(0.154)\end{array}$ \\
\hline $\ln (\text { Outstanding Balance })_{l}$ & $\begin{array}{l}0.131^{* * *} \\
(0.026)\end{array}$ & $\begin{array}{l}0.132^{* * *} \\
(0.026)\end{array}$ & $\begin{array}{l}0.102^{* * *} \\
(0.026)\end{array}$ & $\begin{array}{l}0.100^{* * *} \\
(0.026)\end{array}$ & $\begin{array}{l}0.127^{* * *} \\
(0.019)\end{array}$ & $\begin{array}{l}0.128^{* * *} \\
(0.019)\end{array}$ & $\begin{array}{l}0.127^{* * *} \\
(0.018)\end{array}$ \\
\hline Rating Safe $_{l}$ :Any Measure ${ }_{j}$ & $\begin{array}{r}-0.061 \\
(0.450)\end{array}$ & $\begin{array}{c}-0.021 \\
(0.450)\end{array}$ & $\begin{array}{l}0.378^{* *} \\
(0.172)\end{array}$ & $\begin{array}{l}0.409^{* *} \\
(0.164)\end{array}$ & $\begin{array}{l}0.397^{* *} \\
(0.189)\end{array}$ & $\begin{array}{l}0.400^{* *} \\
(0.188)\end{array}$ & $\begin{array}{l}0.387^{* *} \\
(0.178)\end{array}$ \\
\hline 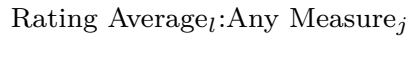 & $\begin{array}{c}-0.274 \\
(0.254)\end{array}$ & $\begin{array}{c}-0.244 \\
(0.254)\end{array}$ & $\begin{array}{c}0.151^{*} \\
(0.081)\end{array}$ & $\begin{array}{l}0.176^{* *} \\
(0.076)\end{array}$ & $\begin{array}{l}0.225^{* * *} \\
(0.077)\end{array}$ & $\begin{array}{l}0.231^{* * *} \\
(0.076)\end{array}$ & $\begin{array}{l}0.217^{* * *} \\
(0.079)\end{array}$ \\
\hline Rating Risky $_{l}$ :Any Measure $_{j}$ & $\begin{array}{c}-0.234 \\
(0.176)\end{array}$ & $\begin{array}{r}-0.210 \\
(0.171)\end{array}$ & $\begin{array}{l}0.190^{* * *} \\
(0.054)\end{array}$ & $\begin{array}{l}0.169^{* * *} \\
(0.047)\end{array}$ & $\begin{array}{l}0.192^{* * *} \\
(0.034)\end{array}$ & $\begin{array}{l}0.197^{* * *} \\
(0.033)\end{array}$ & $\begin{array}{l}0.184^{* * *} \\
(0.035)\end{array}$ \\
\hline Forbearance Before $_{j}$ & & & & & & & $\begin{array}{c}0.019 \\
(0.031) \\
\end{array}$ \\
\hline Fixed Effects: & & & & & & & \\
\hline Loan age & & Yes & Yes & Yes & Yes & Yes & Yes \\
\hline Sector $\mathrm{x}$ Time & & & Yes & Yes & Yes & Yes & Yes \\
\hline Bank x Time & & & & Yes & Yes & Yes & Yes \\
\hline Bank x Segment x Prod. Type & & & & & Yes & Yes & Yes \\
\hline$\underline{\text { County }}$ & & & & & & Yes & Yes \\
\hline Observations & $1,563,456$ & $1,563,456$ & $1,563,456$ & $1,563,456$ & $1,563,456$ & $1,563,456$ & $1,563,456$ \\
\hline
\end{tabular}


Table 7: Logit regression: Probability of default for any loan by borrower - Influence of different measures taken by borrower

\begin{tabular}{|c|c|c|c|c|c|c|}
\hline \multirow[b]{3}{*}{ Measure $_{i}$ : } & \multicolumn{6}{|c|}{ Dependent variable: } \\
\hline & \multicolumn{6}{|c|}{ Probability of Default $_{j}$} \\
\hline & $\begin{array}{c}\text { Any } \\
\text { Measure }_{j} \\
(1)\end{array}$ & $\begin{array}{c}\text { Term } \\
\text { Extension }_{j} \\
(2)\end{array}$ & $\begin{array}{c}\text { Interest } \\
\text { Rate } \\
\text { Change }_{j} \\
\quad(3)\end{array}$ & $\begin{array}{c}\text { Limit } \\
\text { Extension }_{j} \\
(4) \\
\end{array}$ & $\begin{array}{c}\text { Rollover }_{j} \\
(5)\end{array}$ & $\begin{array}{c}\text { Amortisation } \\
\text { Stop }_{j} \\
(6)\end{array}$ \\
\hline Rating Average $e_{l}$ & $\begin{array}{l}1.281^{* * *} \\
(0.118)\end{array}$ & $\begin{array}{l}1.298^{* * *} \\
(0.068)\end{array}$ & $\begin{array}{l}1.294^{* * *} \\
(0.079)\end{array}$ & $\begin{array}{l}1.312^{* * *} \\
(0.063)\end{array}$ & $\begin{array}{l}1.271^{* * *} \\
(0.074)\end{array}$ & $\begin{array}{l}1.235^{* * *} \\
(0.080)\end{array}$ \\
\hline Rating Risky ${ }_{l}$ & $\begin{array}{l}3.010^{* * *} \\
(0.155)\end{array}$ & $\begin{array}{l}3.195^{* * *} \\
(0.072)\end{array}$ & $\begin{array}{l}3.140^{* * *} \\
(0.071)\end{array}$ & $\begin{array}{l}3.161^{* * *} \\
(0.062)\end{array}$ & $\begin{array}{l}3.067^{* * *} \\
(0.064)\end{array}$ & $\begin{array}{l}2.921^{* * *} \\
(0.090)\end{array}$ \\
\hline $\ln \left(\right.$ Outstanding Balance $\left._{l}\right)$ & $\begin{array}{l}0.128^{* * *} \\
(0.019)\end{array}$ & $\begin{array}{l}0.099^{* * *} \\
(0.020)\end{array}$ & $\begin{array}{l}0.144^{* * *} \\
(0.020)\end{array}$ & $\begin{array}{l}0.126^{* * *} \\
(0.017)\end{array}$ & $\begin{array}{l}0.126^{* * *} \\
(0.017)\end{array}$ & $\begin{array}{l}0.131^{* * *} \\
(0.020)\end{array}$ \\
\hline Rating $\mathrm{Safe}_{l}:$ Measure $_{i}$ & $\begin{array}{l}0.400^{* *} \\
(0.188)\end{array}$ & $\begin{array}{l}0.462^{* * *} \\
(0.157)\end{array}$ & $\begin{array}{l}1.535^{* * *} \\
(0.176)\end{array}$ & $\begin{array}{l}0.400^{* * *} \\
(0.102)\end{array}$ & $\begin{array}{l}0.419^{* * *} \\
(0.087)\end{array}$ & $\begin{array}{c}0.402^{*} \\
(0.229)\end{array}$ \\
\hline Rating Average $_{l}:$ Measure $_{i}$ & $\begin{array}{l}0.231^{* * *} \\
(0.076)\end{array}$ & $\begin{array}{l}0.344^{* * *} \\
(0.126)\end{array}$ & $\begin{array}{l}1.085^{* * *} \\
(0.116)\end{array}$ & $\begin{array}{l}0.231^{* * *} \\
(0.086)\end{array}$ & $\begin{array}{l}0.237^{* *} \\
(0.116)\end{array}$ & $\begin{array}{l}0.517^{* * *} \\
(0.109)\end{array}$ \\
\hline Rating Risky $_{l}{\text { : } \text { Measure }_{i}}$ & $\begin{array}{l}0.197^{* * *} \\
(0.033) \\
\end{array}$ & $\begin{array}{l}0.744^{* * *} \\
(0.062) \\
\end{array}$ & $\begin{array}{l}0.266^{* * *} \\
(0.073) \\
\end{array}$ & $\begin{array}{r}-0.015 \\
(0.051) \\
\end{array}$ & $\begin{array}{r}-0.038 \\
(0.034) \\
\end{array}$ & $\begin{array}{l}0.326^{* * *} \\
(0.056)\end{array}$ \\
\hline $\begin{array}{l}\text { Fixed Effects: } \\
\text { Loan age }\end{array}$ & & & & & & \\
\hline Sector x Time & Yes & Yes & Yes & Yes & Yes & Yes \\
\hline Bank x Time & Yes & Yes & Yes & Yes & Yes & Yes \\
\hline Bank x Segment x Prod. Type & Yes & Yes & Yes & Yes & Yes & Yes \\
\hline County & Yes & Yes & Yes & Yes & Yes & Yes \\
\hline Observations & $1,563,456$ & 956,718 & $1,326,984$ & $1,304,332$ & $1,304,332$ & $1,561,260$ \\
\hline
\end{tabular}


Table 8: Logit regression: Probability of default in next period for any loan by borrower - Influence of any measure taken by borrower

\begin{tabular}{|c|c|c|c|c|c|c|c|}
\hline & \multicolumn{7}{|c|}{ Dependent variable: } \\
\hline & \multicolumn{7}{|c|}{ Probability of Default $t+1, j$} \\
\hline & $(1)$ & $(2)$ & $(3)$ & $(4)$ & $(5)$ & $(6)$ & $(7)$ \\
\hline Rating Average $l$ & $\begin{array}{l}0.926^{* * *} \\
(0.208)\end{array}$ & $\begin{array}{l}0.940^{* * *} \\
(0.212)\end{array}$ & $\begin{array}{l}1.026^{* * *} \\
(0.192)\end{array}$ & $\begin{array}{l}1.033^{* * *} \\
(0.198)\end{array}$ & $\begin{array}{l}0.980^{* * *} \\
(0.197)\end{array}$ & $\begin{array}{l}0.981^{* * *} \\
(0.196)\end{array}$ & $\begin{array}{l}0.980^{* * *} \\
(0.196)\end{array}$ \\
\hline Rating Risky ${ }_{l}$ & $\begin{array}{l}3.268^{* * *} \\
(0.353)\end{array}$ & $\begin{array}{l}3.267^{* * *} \\
(0.353)\end{array}$ & $\begin{array}{l}3.279^{* * *} \\
(0.316)\end{array}$ & $\begin{array}{l}3.322^{* * *} \\
(0.326)\end{array}$ & $\begin{array}{l}3.295^{* * *} \\
(0.325)\end{array}$ & $\begin{array}{l}3.294^{* * *} \\
(0.325)\end{array}$ & $\begin{array}{l}3.293^{* * *} \\
(0.325)\end{array}$ \\
\hline $\ln (\text { Outstanding Balance })_{l}$ & $\begin{array}{c}0.015 \\
(0.022)\end{array}$ & $\begin{array}{c}0.018 \\
(0.021)\end{array}$ & $\begin{array}{c}0.003 \\
(0.022)\end{array}$ & $\begin{array}{c}0.003 \\
(0.022)\end{array}$ & $\begin{array}{c}0.011 \\
(0.017)\end{array}$ & $\begin{array}{c}0.012 \\
(0.017)\end{array}$ & $\begin{array}{c}0.011 \\
(0.016)\end{array}$ \\
\hline 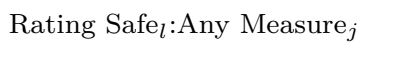 & $\begin{array}{l}0.145 \\
(0.419)\end{array}$ & $\begin{array}{c}0.203 \\
(0.429)\end{array}$ & $\begin{array}{l}0.333 \\
(0.351)\end{array}$ & $\begin{array}{c}0.323 \\
(0.355)\end{array}$ & $\begin{array}{c}0.256 \\
(0.370)\end{array}$ & $\begin{array}{c}0.261 \\
(0.369)\end{array}$ & $\begin{array}{l}0.214 \\
(0.352)\end{array}$ \\
\hline Rating Average $_{l}$ :Any Measure $_{j}$ & $\begin{array}{r}-0.219 \\
(0.226)\end{array}$ & $\begin{array}{c}0.258 \\
(0.231)\end{array}$ & $\begin{array}{l}0.450^{* * *} \\
(0.173)\end{array}$ & $\begin{array}{l}0.446^{* *} \\
(0.176)\end{array}$ & $\begin{array}{l}0.441^{* * *} \\
(0.166)\end{array}$ & $\begin{array}{l}0.446^{* * *} \\
(0.165)\end{array}$ & $\begin{array}{l}0.401^{* * *} \\
(0.149)\end{array}$ \\
\hline 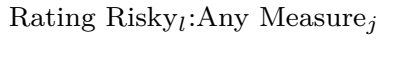 & $\begin{array}{c}0.091 \\
(0.125)\end{array}$ & $\begin{array}{c}0.128 \\
(0.124)\end{array}$ & $\begin{array}{l}0.307^{* * *} \\
(0.101)\end{array}$ & $\begin{array}{l}0.283^{* * *} \\
(0.104)\end{array}$ & $\begin{array}{l}0.274^{* * *} \\
(0.077)\end{array}$ & $\begin{array}{l}0.281^{* * *} \\
(0.077)\end{array}$ & $\begin{array}{l}0.234^{* * *} \\
(0.073)\end{array}$ \\
\hline${\text { Forbearance } \text { Before }_{j}}$ & & & & & & & $\begin{array}{c}0.069 \\
(0.066) \\
\end{array}$ \\
\hline Fixed Effects: & & & & & & & \\
\hline Loan age & & Yes & Yes & Yes & Yes & Yes & Yes \\
\hline Sector $\mathrm{x}$ Time & & & Yes & Yes & Yes & Yes & Yes \\
\hline Bank x Time & & & & Yes & Yes & Yes & Yes \\
\hline Bank x Segment x Prod. Type & & & & & Yes & Yes & Yes \\
\hline County & & & & & & Yes & Yes \\
\hline Observations & $1,292,685$ & $1,292,685$ & $1,292,685$ & $1,292,685$ & $1,292,685$ & $1,292,685$ & $1,292,685$ \\
\hline
\end{tabular}


Table 9: Logit regression: Probability of default in next period for any loan by borrower - Influence of different measures taken by borrower

\begin{tabular}{|c|c|c|c|c|c|c|}
\hline \multirow[b]{3}{*}{ Measure $_{i}$ : } & \multicolumn{6}{|c|}{ Dependent variable: } \\
\hline & \multicolumn{6}{|c|}{ Probability of Default $t+1, j$} \\
\hline & $\begin{array}{c}\text { Any } \\
\text { Measure }_{j} \\
(1) \\
\end{array}$ & $\begin{array}{c}\text { Term } \\
\text { Extension }_{j} \\
(2) \\
\end{array}$ & $\begin{array}{c}\text { Interest } \\
\text { Rate } \\
\text { Change }_{j} \\
(3)\end{array}$ & $\begin{array}{c}\text { Limit } \\
\text { Extension }_{j} \\
(4) \\
\end{array}$ & $\begin{array}{c}\text { Rollover }_{j} \\
(5) \\
\end{array}$ & $\begin{array}{c}\text { Amortisation } \\
\text { Stop }_{j} \\
(6) \\
\end{array}$ \\
\hline Rating Average $e_{l}$ & $\begin{array}{l}0.981^{* * *} \\
(0.196)\end{array}$ & $\begin{array}{l}1.209^{* * *} \\
(0.130)\end{array}$ & $\begin{array}{l}1.153^{* * *} \\
(0.152)\end{array}$ & $\begin{array}{l}1.151^{* * *} \\
(0.119)\end{array}$ & $\begin{array}{l}1.157^{* * *} \\
(0.142)\end{array}$ & $\begin{array}{l}1.053^{* * *} \\
(0.184)\end{array}$ \\
\hline Rating Risky $_{l}$ & $\begin{array}{l}3.294^{* * *} \\
(0.325)\end{array}$ & $\begin{array}{l}3.655^{* * *} \\
(0.153)\end{array}$ & $\begin{array}{l}3.642^{* * *} \\
(0.172)\end{array}$ & $\begin{array}{l}3.638^{* * *} \\
(0.133)\end{array}$ & $\begin{array}{l}3.536^{* * *} \\
(0.152)\end{array}$ & $\begin{array}{l}3.242^{* * *} \\
(0.253)\end{array}$ \\
\hline $\ln \left(\right.$ Outstanding Balance $\left.{ }_{l}\right)$ & $\begin{array}{c}0.012 \\
(0.017)\end{array}$ & $\begin{array}{l}-0.023^{* *} \\
(0.011)\end{array}$ & $\begin{array}{l}0.029^{*} \\
(0.017)\end{array}$ & $\begin{array}{r}-0.001 \\
(0.009)\end{array}$ & $\begin{array}{c}-0.001 \\
(0.009)\end{array}$ & $\begin{array}{c}0.015 \\
(0.018)\end{array}$ \\
\hline Rating $\mathrm{Safe}_{l}:$ Measure $_{i}$ & $\begin{array}{c}0.261 \\
(0.369)\end{array}$ & $\begin{array}{l}1.793^{* * *} \\
(0.324)\end{array}$ & $\begin{array}{l}0.414^{* * *} \\
(0.099)\end{array}$ & $\begin{array}{c}0.290 \\
(0.205)\end{array}$ & $\begin{array}{l}0.250 \\
(0.528)\end{array}$ & $\begin{array}{l}1.006^{*} \\
(0.539)\end{array}$ \\
\hline Rating Average $_{l}:$ Measure $_{i}$ & $\begin{array}{l}0.446^{* * *} \\
(0.165)\end{array}$ & $\begin{array}{l}1.319^{* * *} \\
(0.246)\end{array}$ & $\begin{array}{l}0.444^{* * *} \\
(0.161)\end{array}$ & $\begin{array}{r}0.335^{*} \\
(0.186)\end{array}$ & $\begin{array}{l}0.708^{* *} \\
(0.335)\end{array}$ & $\begin{array}{l}0.762^{* * *} \\
(0.220)\end{array}$ \\
\hline Rating Risky $_{l}$ :Measure $_{i}$ & $\begin{array}{l}0.281^{* * *} \\
(0.077)\end{array}$ & $\begin{array}{c}0.114 \\
(0.130) \\
\end{array}$ & $\begin{array}{c}-0.005 \\
(0.062) \\
\end{array}$ & $\begin{array}{l}-0.251^{* * *} \\
(0.076) \\
\end{array}$ & $\begin{array}{c}0.077 \\
(0.125) \\
\end{array}$ & $\begin{array}{l}1.166^{* * *} \\
(0.092) \\
\end{array}$ \\
\hline Fixed Effects: & & & & & & \\
\hline Loan age & Yes & Yes & Yes & Yes & Yes & Yes \\
\hline Sector x Time & Yes & Yes & $\begin{array}{l}\text { Yes } \\
\text { Yes }\end{array}$ & $\begin{array}{r}\text { Yes } \\
\text { Yes }\end{array}$ & $\begin{array}{l}\text { Yes } \\
\text { Yes }\end{array}$ & $\begin{array}{l}\text { Yes } \\
\text { Yes }\end{array}$ \\
\hline Bank x Time & Yes & Yes & Yes & Yes & Yes & $\begin{array}{l}\text { Yes } \\
\text { Yes }\end{array}$ \\
\hline $\begin{array}{l}\text { Bank x Segment x Prod. Type } \\
\text { County }\end{array}$ & $\begin{array}{l}\text { Yes } \\
\text { Yes }\end{array}$ & $\begin{array}{l}\text { Yes } \\
\text { Yes }\end{array}$ & $\begin{array}{l}\text { Yes } \\
\text { Yes }\end{array}$ & $\begin{array}{l}\text { Yes } \\
\text { Yes }\end{array}$ & $\begin{array}{l}\text { Yes } \\
\text { Yes }\end{array}$ & $\begin{array}{l}\text { Yes } \\
\text { Yes }\end{array}$ \\
\hline Observations & $1,292,685$ & 799,152 & $1,109,815$ & $1,100,091$ & $1,100,091$ & $1,291,121$ \\
\hline
\end{tabular}

Note: Logit Hazard Regression with standard errors clustered at Bank $x$ Time level. The dependent variable is the probability of default of any loan held by borrower $j$ in any period in the future whereas the independent variables are measured in t. We split the borrowers in Safe, Average, and Risky based on their ex-ante probability of default. Measure on loan $l$ is specified by the heading of each column. The loan exits the sample once a default occurs. Significance levels: ${ }^{*} p<0.1$; ${ }^{* *} p<0.05 ;{ }^{* * *} p<0.01$

Table 10: OLS regression: Relationship between forbearance and new lending by buckets: County $\times$ Time $\times$ Bank $\times$ Segment

\begin{tabular}{|c|c|c|c|c|c|c|}
\hline & \multicolumn{6}{|c|}{ Dependent variable: } \\
\hline & \multicolumn{5}{|c|}{ Share(New Lending $t)$} & \multirow{2}{*}{$\begin{array}{c}\ln (\mathrm{New} \\
\left.\text { Lending }_{t}\right) \\
(6)\end{array}$} \\
\hline & (1) & $(2)$ & $(3)$ & $(4)$ & $(5)$ & \\
\hline Share(Forbearance $)_{t-1}$ & $\begin{array}{c}-0.034^{* * *} \\
\quad(0.007)\end{array}$ & $\begin{array}{c}-0.053^{* * *} \\
(0.007)\end{array}$ & $\begin{array}{c}-0.066^{* * *} \\
(0.007)\end{array}$ & $\begin{array}{c}-0.076^{* * *} \\
(0.008)\end{array}$ & & \\
\hline Share $(\text { Forbearance })_{t}$ & & & & & $\begin{array}{c}-0.045^{* * *} \\
(0.011)\end{array}$ & \\
\hline $\ln (\text { Forbearance })_{t}$ & & & & & & $\begin{array}{c}-0.160^{* * *} \\
(0.042) \\
\end{array}$ \\
\hline \multicolumn{7}{|l|}{ Fixed Effects: } \\
\hline Bank & & Yes & Yes & & & \\
\hline County x Time & & & Yes & Yes & Yes & Yes \\
\hline Bank x Time & & & & Yes & Yes & Yes \\
\hline Observations & 754 & 754 & 754 & 754 & 873 & 872 \\
\hline $\mathrm{R}^{2}$ & 0.033 & 0.136 & 0.383 & 0.419 & 0.290 & 0.597 \\
\hline Adjusted $\mathrm{R}^{2}$ & 0.032 & 0.134 & 0.144 & 0.185 & 0.011 & 0.438 \\
\hline
\end{tabular}

Note: OLS Regressions saturated with fixed effects. The dependent variable is the volume-weighted share of new lending (1)-(5) or the ln of new lending (6) per bucket of borrowers within a bank, segment, and county. The independent variable is the volume-weighted share of forborne loans in $t-1$ or $t$ (first two lines) or the ln of the sum of forborne loans in $t$ (last line). Significance levels: ${ }^{*} p<0.1 ;{ }^{* *} p<0.05 ;{ }^{* * *} p<0.01$ 


\section{Appendix}

\section{Additional Graphs}

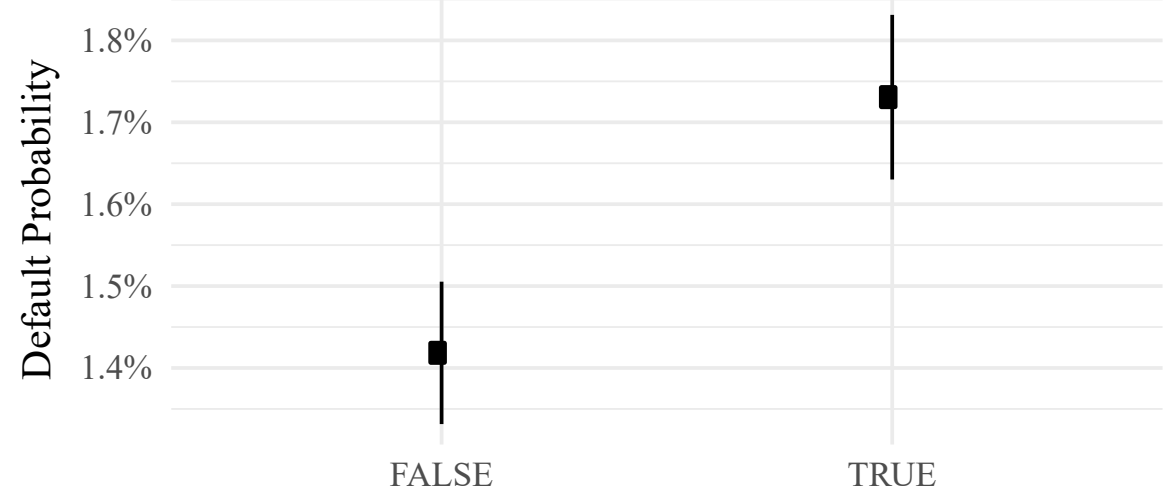

Any measure

Figure 8: Predicted probability of default for a loan, depending on any measure being taken and any measure having been taken before. All other variables at mean or mode.

Source: Author's Calculations; Data: CBI 


\section{Additional Tables}

Table 11: Robustness: Additional double interaction term Texas Ratio $\times$ Outstanding Balance

\begin{tabular}{|c|c|c|c|c|c|c|c|}
\hline & \multicolumn{7}{|c|}{ Dependent variable: } \\
\hline & \multicolumn{7}{|c|}{${\text { Any } \text { Measure }_{j}}$} \\
\hline$\overline{\text { Rating Average }_{l}}$ & $\begin{array}{c}-0.149 \\
(0.299)\end{array}$ & $\begin{array}{c}-0.132 \\
(0.298)\end{array}$ & $\begin{array}{c}-0.199 \\
(0.241)\end{array}$ & $\begin{array}{c}0.031 \\
(0.124)\end{array}$ & $\begin{array}{c}-0.149 \\
(0.115)\end{array}$ & $\begin{array}{c}-0.158 \\
(0.115)\end{array}$ & $\begin{array}{c}-0.088 \\
(0.173)\end{array}$ \\
\hline Rating Risky ${ }_{l}$ & $\begin{array}{r}-0.845 \\
(0.587)\end{array}$ & $\begin{array}{r}-0.857 \\
(0.590)\end{array}$ & $\begin{array}{l}-0.888^{* * *} \\
(0.339)\end{array}$ & $\begin{array}{r}-0.409 \\
(0.271)\end{array}$ & $\begin{array}{c}-0.565^{* *} \\
(0.263)\end{array}$ & $\begin{array}{l}-0.579^{* *} \\
(0.264)\end{array}$ & $\begin{array}{l}-0.597^{* *} \\
(0.275)\end{array}$ \\
\hline $\ln \left(\right.$ Out. Bal. $\left.{ }_{l}\right)$ & $\begin{array}{l}0.271^{* *} \\
(0.105)\end{array}$ & $\begin{array}{l}0.264^{* *} \\
(0.107)\end{array}$ & $\begin{array}{l}0.261^{* *} \\
(0.108)\end{array}$ & $\begin{array}{l}0.244^{* *} \\
(0.109)\end{array}$ & $\begin{array}{l}0.180^{* *} \\
(0.083)\end{array}$ & $\begin{array}{l}0.178^{* *} \\
(0.083)\end{array}$ & $\begin{array}{l}0.185^{* *} \\
(0.086)\end{array}$ \\
\hline $\ln \left(\right.$ Out. Bal. $\left.{ }_{l}\right)$ :Texas Ratio $k$ & $\begin{array}{c}-0.001 \\
(0.001)\end{array}$ & $\begin{array}{c}-0.001 \\
(0.001)\end{array}$ & $\begin{array}{c}-0.001 \\
(0.001)\end{array}$ & $\begin{array}{c}-0.0003 \\
(0.001)\end{array}$ & $\begin{array}{c}-0.0005 \\
(0.001)\end{array}$ & $\begin{array}{c}-0.0005 \\
(0.001)\end{array}$ & $\begin{array}{c}-0.001 \\
(0.001)\end{array}$ \\
\hline Rating Average $_{l}$ :Texas Ratio $_{k}$ & $\begin{array}{l}0.003 \\
(0.003)\end{array}$ & $\begin{array}{c}0.003 \\
(0.003)\end{array}$ & $\begin{array}{c}0.003 \\
(0.003)\end{array}$ & $\begin{array}{c}0.001 \\
(0.001)\end{array}$ & $\begin{array}{l}0.003^{* *} \\
(0.001)\end{array}$ & $\begin{array}{l}0.003^{* *} \\
(0.001)\end{array}$ & $\begin{array}{c}0.002 \\
(0.002)\end{array}$ \\
\hline Rating Risky ${ }_{l}$ :Texas Ratio ${ }_{k}$ & $\begin{array}{c}0.009 \\
(0.006)\end{array}$ & $\begin{array}{c}0.009 \\
(0.006)\end{array}$ & $\begin{array}{l}0.011^{* * *} \\
(0.004)\end{array}$ & $\begin{aligned} 0.006^{*} \\
(0.003)\end{aligned}$ & $\begin{array}{l}0.008^{* * *} \\
(0.003)\end{array}$ & $\begin{array}{l}0.008^{* * *} \\
(0.003)\end{array}$ & $\begin{array}{l}0.008^{* *} \\
(0.003)\end{array}$ \\
\hline Forbearance Before ${ }_{k}$ & & & & & & & $\begin{array}{l}1.179^{* * *} \\
(0.098)\end{array}$ \\
\hline $\begin{array}{l}\text { Fixed Effects: } \\
\text { Loan age }\end{array}$ & & Yes & Yes & Yes & Yes & Yes & Yes \\
\hline Sector x Time & & & Yes & Yes & Yes & Yes & Yes \\
\hline Bank x Time & & & & Yes & Yes & Yes & Yes \\
\hline Bank x Segment x Prod. Type & & & & & Yes & Yes & Yes \\
\hline County & & & & & & Yes & Yes \\
\hline Observations & $1,393,284$ & $1,393,284$ & $1,393,284$ & $1,393,284$ & $1,393,284$ & $1,393,284$ & $1,324,317$ \\
\hline
\end{tabular}

Note: Logit Regression with standard errors clustered at Bank $x$ Time level. The dependent variable is the probability of receiving forbearance in $t+1$ whereas the independent variables are measured in $t$. A Texas Ratio of $100 \%$ corresponds to a value of 100 in the regression. We split the borrowers in Safe, Average and Risky based on their ex-ante probability of default. Forbearance Before is a dummy which is one if a borrower has ever received forbearance before $t+1$. Significance levels: ${ }^{*} p<0.1 ;{ }^{* *} p<0.05 ;{ }^{* * *} p<0.01$ 
Table 12: Logit regression: Probability of default in one to six periods ahead for any loan by borrower Influence of different measures taken by borrower

\begin{tabular}{|c|c|c|c|c|c|c|}
\hline \multirow[b]{2}{*}{ Time: } & \multicolumn{6}{|c|}{ Dependent variable: Probability of Default ${ }_{j}$} \\
\hline & $\begin{array}{c}\mathrm{t}+1 \\
(1)\end{array}$ & $\begin{array}{c}\mathrm{t}+2 \\
(2)\end{array}$ & $\begin{array}{c}\mathrm{t}+3 \\
(3)\end{array}$ & $\begin{array}{c}t+4 \\
(4)\end{array}$ & $\begin{array}{c}\mathrm{t}+5 \\
(5)\end{array}$ & $\begin{array}{c}\mathrm{t}+6 \\
(6)\end{array}$ \\
\hline $\begin{array}{r}\text { Rating - Risky }{ }_{l} \text { :Any measure }{ }_{j} \\
\text { Observations }\end{array}$ & $\begin{array}{l}0.281^{* * *} \\
(0.077) \\
1,292,685\end{array}$ & $\begin{array}{l}0.246^{* * *} \\
(0.050) \\
1,082,965\end{array}$ & $\begin{array}{l}0.269^{* * *} \\
(0.043) \\
888,638\end{array}$ & $\begin{array}{l}0.273^{* * *} \\
(0.040) \\
721,261\end{array}$ & $\begin{array}{l}0.274^{* * *} \\
(0.039) \\
556,138\end{array}$ & $\begin{array}{l}0.284^{* * *} \\
(0.020) \\
407,507\end{array}$ \\
\hline $\begin{array}{r}\text { Rating - Risky }{ }_{l} \text { :Term extension }{ }_{j} \\
\text { Observations }\end{array}$ & $\begin{array}{l}0.114 \\
(0.130) \\
799,152\end{array}$ & $\begin{array}{l}0.218^{* *} \\
(0.090) \\
657,785\end{array}$ & $\begin{array}{l}0.212^{* * *} \\
(0.073) \\
526,096\end{array}$ & $\begin{array}{l}0.202^{* * *} \\
(0.060) \\
410,257\end{array}$ & $\begin{array}{l}0.196^{* * *} \\
(0.057) \\
296,674\end{array}$ & $\begin{array}{l}0.233^{* * *} \\
(0.038) \\
194,008\end{array}$ \\
\hline $\begin{array}{r}\text { Rating }- \text { Risky }_{l} \text { :Interest rate change }{ }_{j} \\
\text { Observations }\end{array}$ & $\begin{array}{l}-0.005 \\
(0.062) \\
1,109,815\end{array}$ & $\begin{array}{l}-0.013 \\
(0.054) \\
919,948\end{array}$ & $\begin{array}{l}0.052 \\
(0.048) \\
741,435\end{array}$ & $\begin{array}{l}0.057 \\
(0.061) \\
586,613\end{array}$ & $\begin{array}{l}0.150^{* * *} \\
(0.051) \\
432,833\end{array}$ & $\begin{array}{l}0.148^{* * *} \\
(0.011) \\
294,974\end{array}$ \\
\hline $\begin{array}{r}\text { Rating - Risky }{ }_{l} \text { Limit extension }_{j} \\
\text { Observations }\end{array}$ & $\begin{array}{l}-0.251^{* * *} \\
(0.076) \\
1,100,091\end{array}$ & $\begin{array}{l}-0.133^{* * *} \\
(0.050) \\
915,549\end{array}$ & $\begin{array}{c}-0.050 \\
(0.042) \\
740,629\end{array}$ & $\begin{array}{l}-0.049 \\
(0.044) \\
587,655\end{array}$ & $\begin{array}{c}-0.031 \\
(0.036) \\
435,649\end{array}$ & $\begin{array}{l}-0.041 \\
(0.052) \\
298,885\end{array}$ \\
\hline $\begin{array}{r}\text { Rating }- \text { Risky }_{l} \text { :Rollover } \\
\\
\text { Observations }\end{array}$ & $\begin{array}{l}0.077 \\
(0.125) \\
1,100,091\end{array}$ & $\begin{array}{l}0.329^{* * *} \\
(0.062) \\
915,549\end{array}$ & $\begin{array}{l}0.434^{* * *} \\
(0.047) \\
740,629\end{array}$ & $\begin{array}{l}0.493^{* * *} \\
(0.041) \\
587,655\end{array}$ & $\begin{array}{l}0.491^{* * *} \\
(0.044) \\
435,649\end{array}$ & $\begin{array}{l}0.417^{* * *} \\
(0.089) \\
298,885\end{array}$ \\
\hline $\begin{array}{r}\text { Rating }- \text { Risky }_{l} \text { :Amortisation } \text { Stop }_{j} \\
\text { Observations }\end{array}$ & $\begin{array}{l}1.166^{* * *} \\
(0.092) \\
1,291,121\end{array}$ & $\begin{array}{l}1.019^{* * *} \\
(0.082) \\
1,081,726\end{array}$ & $\begin{array}{l}0.911^{* * *} \\
(0.077) \\
887,638\end{array}$ & $\begin{array}{l}0.858^{* * *} \\
(0.075) \\
720,434\end{array}$ & $\begin{array}{l}0.771^{* * *} \\
(0.068) \\
555,471\end{array}$ & $\begin{array}{l}0.674^{* * *} \\
(0.072) \\
406,982\end{array}$ \\
\hline $\begin{array}{l}\text { Fixed Effects: } \\
\text { Loan age } \\
\text { Sector x Time } \\
\text { Bank x Time } \\
\text { Bank x Segment x Product Type } \\
\text { Region }\end{array}$ & $\begin{array}{l}\text { Yes } \\
\text { Yes } \\
\text { Yes } \\
\text { Yes } \\
\text { Yes }\end{array}$ & $\begin{array}{l}\text { Yes } \\
\text { Yes } \\
\text { Yes } \\
\text { Yes } \\
\text { Yes }\end{array}$ & $\begin{array}{l}\text { Yes } \\
\text { Yes } \\
\text { Yes } \\
\text { Yes } \\
\text { Yes }\end{array}$ & $\begin{array}{l}\text { Yes } \\
\text { Yes } \\
\text { Yes } \\
\text { Yes } \\
\text { Yes }\end{array}$ & $\begin{array}{l}\text { Yes } \\
\text { Yes } \\
\text { Yes } \\
\text { Yes } \\
\text { Yes }\end{array}$ & $\begin{array}{l}\text { Yes } \\
\text { Yes } \\
\text { Yes } \\
\text { Yes } \\
\text { Yes }\end{array}$ \\
\hline
\end{tabular}

Note: Logit Hazard Regression with standard errors clustered at Bank x Time level. The dependent variable is the probability of default of any loan held by borrower $j$ in one to six periods in the future whereas the independent variables are measured in $t$. We split the borrowers in Safe, Average, and Risky based on their ex-ante probability of default. The loan exits the sample once a default occurs. Significance levels: ${ }^{*} p<0.1 ;{ }^{* *} p<0.05 ;{ }^{* * *} p<0.01$ 
Table 13: Logit regression: Probability of application of any forbearance measure - NPL Ratio and Tier 1 Ratio

\begin{tabular}{|c|c|c|c|c|c|c|c|c|c|}
\hline & \multicolumn{9}{|c|}{ Dependent variable: Any measure ${ }_{j}$} \\
\hline & (1) & (2) & (3) & (4) & (5) & (6) & (7) & (8) & (9) \\
\hline Rating Average ${ }_{l}$ & $\begin{array}{c}-0.150 \\
(0.218)\end{array}$ & $\begin{array}{c}-0.134 \\
(0.220)\end{array}$ & $\begin{array}{c}-0.138 \\
(0.177)\end{array}$ & $\begin{array}{c}0.032 \\
(0.076)\end{array}$ & $\begin{array}{c}-0.051 \\
(0.060)\end{array}$ & $\begin{array}{c}-0.055 \\
(0.059)\end{array}$ & $\begin{array}{c}-0.036 \\
(0.100)\end{array}$ & $\begin{array}{c}0.136 \\
(0.427)\end{array}$ & $\begin{array}{c}-0.828^{*} \\
(0.435)\end{array}$ \\
\hline Rating Risky $l_{l}$ & $\begin{array}{l}-0.829^{* * *} \\
(0.309)\end{array}$ & $\begin{array}{l}-0.844^{* * *} \\
(0.311)\end{array}$ & $\begin{array}{l}-0.568^{* * *} \\
(0.198)\end{array}$ & $\begin{array}{l}-0.400^{* * *} \\
(0.124)\end{array}$ & $\begin{array}{l}-0.400^{* * *} \\
(0.109)\end{array}$ & $\begin{array}{l}-0.412^{* * *} \\
(0.108)\end{array}$ & $\begin{array}{l}-0.344^{* *} \\
(0.149)\end{array}$ & $\begin{array}{l}0.219 \\
(0.563)\end{array}$ & $\begin{aligned}-0.875^{*} \\
(0.466)\end{aligned}$ \\
\hline $\ln \left(\right.$ Outstanding Balance $\left._{l}\right)$ & $\begin{array}{l}0.219^{* * *} \\
(0.013)\end{array}$ & $\begin{array}{l}0.214^{* * *} \\
(0.013)\end{array}$ & $\begin{array}{l}0.208^{* * *} \\
(0.013)\end{array}$ & $\begin{array}{l}0.213^{* * *} \\
(0.013)\end{array}$ & $\begin{array}{l}0.133^{* * *} \\
(0.008)\end{array}$ & $\begin{array}{l}0.132^{* * *} \\
(0.008)\end{array}$ & $\begin{array}{l}0.098^{* * *} \\
(0.008)\end{array}$ & $\begin{array}{l}0.096^{* * *} \\
(0.009)\end{array}$ & $\begin{array}{l}0.098^{* * *} \\
(0.008)\end{array}$ \\
\hline NPL Ratio $_{k}$ & $\begin{array}{c}-0.029 \\
(0.018)\end{array}$ & $\begin{array}{c}-0.030^{*} \\
(0.018)\end{array}$ & $\begin{array}{l}-0.048^{* * *} \\
(0.018)\end{array}$ & & & & & & \\
\hline Rating Average $_{l}:$ NPL Ratio $_{k}$ & $\begin{array}{l}0.017 \\
(0.013)\end{array}$ & $\begin{array}{c}0.019 \\
(0.013)\end{array}$ & $\begin{array}{l}0.017^{* *} \\
(0.007)\end{array}$ & $\begin{array}{c}0.002 \\
(0.003)\end{array}$ & $\begin{array}{l}0.006^{* *} \\
(0.003)\end{array}$ & $\begin{array}{l}0.006^{* *} \\
(0.002)\end{array}$ & $\begin{array}{c}0.004 \\
(0.003)\end{array}$ & & $\begin{array}{l}0.008^{* * *} \\
(0.003)\end{array}$ \\
\hline Rating Risky $_{l}:$ NPL Ratio $_{k}$ & $\begin{array}{l}0.030^{* *} \\
(0.014)\end{array}$ & $\begin{array}{l}0.032^{* *} \\
(0.014)\end{array}$ & $\begin{array}{l}0.028^{* * *} \\
(0.008)\end{array}$ & $\begin{array}{l}0.020^{* * *} \\
(0.005)\end{array}$ & $\begin{array}{l}0.022^{* * *} \\
(0.005)\end{array}$ & $\begin{array}{l}0.023^{* * *} \\
(0.005)\end{array}$ & $\begin{array}{l}0.019^{* * *} \\
(0.006)\end{array}$ & & $\begin{array}{l}0.024^{* * *} \\
(0.006)\end{array}$ \\
\hline 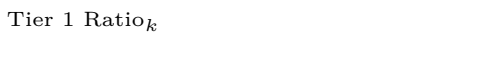 & $\begin{array}{c}-0.030 \\
(0.041)\end{array}$ & $\begin{array}{c}-0.029 \\
(0.041)\end{array}$ & $\begin{array}{c}0.161 \\
(0.111)\end{array}$ & & & & & & \\
\hline Rating Average $l_{l}:$ Tier 1 Ratio $_{k}$ & $\begin{array}{c}0.040 \\
(0.034)\end{array}$ & $\begin{array}{l}0.041 \\
(0.035)\end{array}$ & $\begin{array}{c}0.023 \\
(0.027)\end{array}$ & & & & & $\begin{array}{c}-0.001 \\
(0.026)\end{array}$ & $\begin{array}{l}0.041^{*} \\
(0.024)\end{array}$ \\
\hline Rating Risky $_{l}$ :Tier 1 Ratio $_{k}$ & $\begin{array}{l}0.067^{*} \\
(0.039)\end{array}$ & $\begin{array}{l}0.067^{*} \\
(0.040)\end{array}$ & $\begin{array}{l}0.041 \\
(0.031)\end{array}$ & & & & & $\begin{array}{r}-0.003 \\
(0.034)\end{array}$ & $\begin{array}{l}0.023 \\
(0.027)\end{array}$ \\
\hline $\ln \left(\right.$ Gross Loans $\left._{k}\right)$ & $\begin{array}{l}1.338 \\
(1.589)\end{array}$ & $\begin{array}{l}1.475 \\
(1.598)\end{array}$ & $\begin{array}{c}0.264 \\
(1.110)\end{array}$ & & & & & & \\
\hline Rating - Average $l: \ln \left(\right.$ Gross Loans $\left._{k}\right)$ & $\begin{array}{c}-1.004 \\
(1.472)\end{array}$ & $\begin{array}{r}-1.116 \\
(1.479)\end{array}$ & $\begin{array}{c}-1.166 \\
(0.870)\end{array}$ & & & & & & \\
\hline Rating - Risky $l: \ln \left(\right.$ Gross Loans $\left._{k}\right)$ & $\begin{array}{r}-1.677 \\
(1.459)\end{array}$ & $\begin{array}{c}-1.828 \\
(1.470)\end{array}$ & $\begin{array}{r}-1.392 \\
(0.864)\end{array}$ & & & & & & \\
\hline Loans/Deposits $k$ & $\begin{array}{l}0.002 \\
(0.026)\end{array}$ & $\begin{array}{l}0.001 \\
(0.026)\end{array}$ & $\begin{array}{l}-0.039^{* *} \\
(0.015)\end{array}$ & & & & & & \\
\hline Rating - Average $l:$ Loans $_{\text {Leposits }} k$ & $\begin{array}{c}-0.004 \\
(0.023)\end{array}$ & $\begin{array}{r}-0.003 \\
(0.023)\end{array}$ & $\begin{array}{c}0.013 \\
(0.012)\end{array}$ & & & & & & \\
\hline Rating - Risky ${ }_{l}:$ Loans/Deposits $k$ & $\begin{array}{c}-0.004 \\
(0.024)\end{array}$ & $\begin{array}{c}-0.003 \\
(0.024)\end{array}$ & $\begin{array}{c}0.011 \\
(0.013)\end{array}$ & & & & & & \\
\hline Op. Profit/Avg. Assets $k$ & $\begin{array}{l}0.332 \\
(0.271)\end{array}$ & $\begin{array}{l}0.339 \\
(0.267)\end{array}$ & $\begin{array}{l}1.249^{* *} \\
(0.585)\end{array}$ & & & & & & \\
\hline Rating - Average $l$ :Op. Profit/Avg. Assets $k$ & $\begin{array}{r}-0.179 \\
(0.198)\end{array}$ & $\begin{array}{r}-0.180 \\
(0.196)\end{array}$ & $\begin{array}{c}0.055 \\
(0.096)\end{array}$ & & & & & & \\
\hline Rating - Risky $l$ :Op. Profit/Avg. Assets $k$ & $\begin{array}{r}-0.372 \\
(0.235)\end{array}$ & $\begin{array}{r}-0.378 \\
(0.234)\end{array}$ & $\begin{array}{c}-0.082 \\
(0.120)\end{array}$ & & & & & & \\
\hline Forbearance Before $_{j}$ & & & & & & & $\begin{array}{l}1.175^{* * *} \\
(0.099)\end{array}$ & $\begin{array}{l}1.177^{* * *} \\
(0.098)\end{array}$ & $\begin{array}{l}1.175^{* * *} \\
(0.098)\end{array}$ \\
\hline Fixed Effects: & & & & & & & & & \\
\hline Loa & & Yes & Yes & Yes & Yes & Yes & Yes & Yes & Yes \\
\hline $\begin{array}{l}\text { Sect } \\
\text { Ban }\end{array}$ & & & Yes & $\begin{array}{l}\text { Yes } \\
\text { Yes }\end{array}$ & $\begin{array}{l}\text { Yes } \\
\text { Yes }\end{array}$ & $\begin{array}{l}\text { Yes } \\
\text { Yes }\end{array}$ & $\begin{array}{l}\text { Yes } \\
\text { Yes }\end{array}$ & $\begin{array}{l}\text { Yes } \\
\text { Yes }\end{array}$ & $\begin{array}{l}\text { Yes } \\
\text { Yes }\end{array}$ \\
\hline $\begin{array}{l}\text { Bank x Time } \\
\text { Bank x Segme }\end{array}$ & & & & Yes & $\begin{array}{l}\text { Yes } \\
\text { Yes }\end{array}$ & $\begin{array}{l}\text { Yes } \\
\text { Yes }\end{array}$ & $\begin{array}{l}\text { Yes } \\
\text { Yes }\end{array}$ & $\begin{array}{l}\text { Yes } \\
\text { Yes }\end{array}$ & $\begin{array}{l}\text { Yes } \\
\text { Yes }\end{array}$ \\
\hline ent x Prod. Type & & & & & & Yes & Yes & Yes & Yes \\
\hline Observations & $1,393,284$ & $1,393,284$ & $1,393,284$ & $1,393,284$ & $1,393,284$ & $1,393,284$ & $1,324,317$ & $1,324,317$ & $1,324,317$ \\
\hline
\end{tabular}

Note: Logit Regression with standard errors clustered at Bank $x$ Time level. The dependent variable is the probability of receiving forbearance in $t+1$ whereas the independent variables are measured in $t$. A value of $100 \%$ of any ratio in this table corresponds to a value of 100 in the regression. We split the borrowers in Safe, Average and Risky based on their ex-ante probability of default. Forbearance Before is a
dummy which is one if a borrower has ever received forbearance before $t+1$. Significance levels: ${ }^{*} p<0.1 ;{ }^{* *} p<0.05 ;{ }^{* * *} p<0.01$ 


\section{Description of variables}

All of our forbearance measures are dummy variables that switch to 1 if the forbearance measure $i$ has been applied in time $t$. In the following, we provide the exact definition for each measure.

\section{Rollover}

A loan is considered rolled over if for a given borrower one of its significant loans disappears from the sample (expired or concordantly ended) but the borrower limit does not decrease by more than half of the expired loan's amount. This implies that limits on other products were increased or new products issued to increase the borrower limit. A loan is considered significant if it makes up for at least half of the total borrower limit.

\section{Change in interest rate}

In essence, we use the definition of "zombie lending" by Caballero et al. (2008) which we extend to account for the environment of decreasing interest rates for the our sample period. Therefore, we first calculate the percentage change in the interest rate per loan across time, $\Delta r_{l}$ followed by the average change in the interest rate for buckets, $\Delta r_{b}$, by: Sector, Segment, Product Type, and Rating. Next, we take the deviation of an individual loan from its bucket mean, $\Delta r_{l, b}=\Delta r_{l}-\Delta r_{b}$. Finally, we define an advantageous change in the interest if this decrease in deviation from the bucket mean is larger than that of the lowest decile of the two best rating categories, $\Delta r_{l, b}<\Delta r_{l, b} \|$ lowest decile of best rating categories.

\section{Amortisation stop}

We extract this information on the basis of the banks' reports whether a loan is amortising or not. Therefore, this dummy variable is 1 if a loan switches from amortising to non amortising and 0 otherwise.

\section{Limit extension}

This dummy variable is 1 if we observe an increase in the borrower's total limit (sum of all loans). 


\section{Term extension}

This variable is defined by whether we see a positive change of the maturity of a loan product.

\section{Overall forbearance dummy}

The overall forbearance dummy switches to 1 if any loan of a borrower received any of the these forbearance measures in a given period.

\section{Abbreviations}

EBA European Banking Authority

F-IRB Foundation-Internal Ratings Based

IFRS International Financial Reporting Standards

IMF International Monetary Fund

NPL Non-performing Loans

OMT Outright Monetary Transactions

REA Risk Exposure Amount

SME Small Medium Enterprise 